\title{
13. DIAGENESIS AND CEMENTATION OF LOWER MIOCENE PYROCLASTIC SEQUENCES IN THE SULU SEA, SITES 768, 769, AND 771 ${ }^{1}$
}

\author{
Randall B. Smith ${ }^{2,3}$
}

\begin{abstract}
Thick, lithologically homogeneous sequences of lower Miocene marine tuff and lapillistone were drilled at three sites in the Sulu Sea during Ocean Drilling Program Leg 124. Extensive diagenetic alteration of vitric, rhyolitic to basaltic ash occurred during burial, at inferred temperatures between $50^{\circ}$ and $100^{\circ} \mathrm{C}$. Alteration of glass and olivine in most rocks was complete, whereas plagioclase is only partially altered, and clinopyroxene and hornblende are unaltered. Smectite and alkali zeolites are the dominant diagenetic minerals, occurring as replacements of glass, as intergranular cements, and as fillings of secondary voids caused by dissolution of glass. The composition of the zeolite assemblage varies with glass composition and burial depth.

Siliceous, pumice-rich tuff and lapillistone more than $200 \mathrm{~m}$ thick overlie oceanic crust at Site 768 in the southeast Sulu Basin and are buried beneath $880 \mathrm{~m}$ of younger strata. Authigenic smectite, celadonite, clinoptilolite, and mordenite occur through most of the tuff section, but are partially replaced by chlorite, heulandite, and analcime in the lower $60 \mathrm{~m}$ of the section. Two sites on the Cagayan Ridge ( 769 and 771 ) penetrated 60 to $100 \mathrm{~m}$ into acoustic basement, which consists of basaltic tuff and lapillistone, overlain by 200 to $280 \mathrm{~m}$ of sediment. The dominant authigenic minerals throughout the pyroclastic section are phillipsite and a trioctahedral smectite (saponite) rich in $\mathrm{Mg}$ and $\mathrm{Fe}$. Analcime accompanies them at deeper levels, replacing vitric clasts and plagioclase. The absence of authigenic Fe-hydroxides and celadonite in the basaltic tuffs indicates that diagenesis was non-oxidative. Circulating pore waters within the basaltic tuffs were probably isolated from oxygenated bottom waters during glass alteration by the sealing effect of overlying, impermeable claystone and marl.

The overall paragenetic sequence of authigenic minerals at the Sulu Sea sites is (1) smectite; (2) alkali zeolites (phillipsite, mordenite, clinoptilolite); (3) analcime. Alteration of the pyroclastic strata was aided by the abundance of unstable glass, high porosity and permeability of the deposits, the large effective surface area of highly vesicular glassy pyroclasts, and the elevated heat flow due to deposition and burial in a back-arc basin setting.
\end{abstract}

\section{INTRODUCTION}

The Sulu Sea, lying between the Philippines and northern Borneo, is one of the smallest marginal basins in the southwest Pacific region (Fig. 1). The age and origin of the Sulu Sea have recently been subjects of much discussion and conflicting interpretations (Lee and McCabe, 1986; Mitchell et al., 1986; Rangin, 1989). The results of Leg 124 drilling at three Sulu Sea sites during the Ocean Drilling Program indicate that the southeast Sulu Basin formed in early Miocene time, concurrent with extensive explosive volcanism within a flanking arc terrane. Thick sequences of lower Miocene or older pyroclastic strata were deposited at each of the Sulu Sea sites $(768,769$, and 771). These pyroclastic deposits are now lithified and buried under younger sedimentary strata, and represent the thickest and most lithologically homogeneous sequences of arc-derived volcaniclastic deposits recovered to date by deep-sea drilling in a back-arc basin. The objective of this study was to document the nature and sequence of diagenetic changes that have occurred during burial of these pyroclastic strata.

The composition of the early Miocene pyroclastic deposits varies with the geologic setting of the three Sulu Sea sites. The submerged, northeast-trending Cagayan Ridge divides the Sulu Sea into two distinct basins (Fig. 1). The northwest Sulu Basin floor is only $1500-2000 \mathrm{~m}$ below sea level, and the basin

\footnotetext{
1 Silver, E. A., Rangin, C., von Breymann, M. T., et al., 1991. Proc. ODP Sci. Results, 124: College Station, TX (Ocean Drilling Program).

${ }^{2}$ Department of Geology, California State University, Fresno, CA 93740 , U.S.A.

${ }^{3}$ Now at Department of Geology, Sonoma State University, Rohnert Park. CA 93928, U.S.A.
}

has a thick crust $(>10 \mathrm{~km})$ overlain by a thick, highly deformed sedimentary sequence (Rangin, 1989); this basin was not investigated during Leg 124 . The deeper southeast Sulu Basin attains water depths of 4500 to $5100 \mathrm{~m}$ and has a sediment cover 1 to $2 \mathrm{~km}$ thick overlying oceanic crust. Site 768 was drilled on the floor of the southeast basin, and recovered a sedimentary sequence $1043.6 \mathrm{~m}$ thick (Fig. 2), as well as penetrating $225 \mathrm{~m}$ into the oceanic basement (Shipboard Scientific Party, 1990a). Thick graded beds of tuff and lapillistone of rhyolitic to andesitic composition occur interbedded with brown claystone in the basal $43 \mathrm{~m}$ of the sediment column (Unit V), and make up all of the overlying Unit IV, which is $197 \mathrm{~m}$ thick. The pumice-rich tephra was erupted from a shallow-water or subaerial vent, and deposited on the basin floor by gravity-driven submarine flows.

The Cagayan Ridge has summit depths between 500 and $2000 \mathrm{~m}$. It is asymmetric in profile, with a smooth northwestern slope and a steep southeastern margin marked by southeast-facing normal fault scarps. Volcanic rocks and tuffs ranging from basaltic andesite to dacite in composition were recently dredged from twelve localities on the eastern flank of the Cagayan Ridge (Kudrass et al., 1990), confirming earlier suggestions that the ridge has a volcanic basement (Mascle and Biscarrat, 1979; Hamilton, 1979). The volcanic rocks are draped by younger sediments, and stratigraphic and geochronologic evidence suggest that volcanism ceased in early or early middle Miocene time (Kudrass et al., 1990; Shipboard Scientific Party, 1990b, 1990c). The Cagayan Ridge has been interpreted as an extinct north-facing island arc associated with the Palawan Trench (Holloway, 1982) or as a remnant arc rifted from the Sulu arc during opening of the southeast Sulu Basin (Mitchell et al., 1986; Rangin, 1989). 


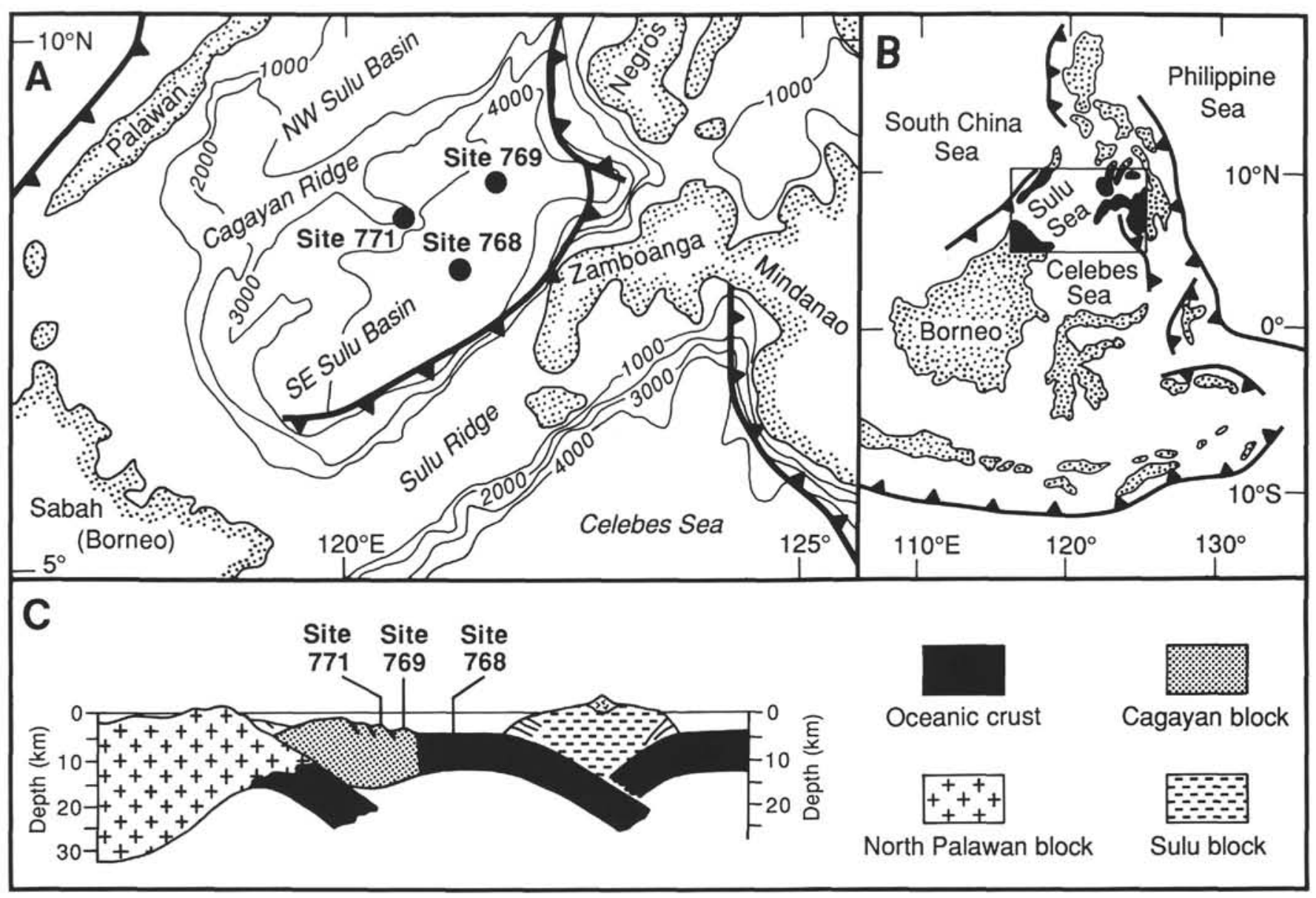

Figure 1. Location and geologic setting of Leg 124 drill sites in the Sulu Sea. A. Simplified bathymetric map of the Sulu Sea with site locations. Bathymetric contours in meters. B. Location map of the Sulu Sea region. Rectangle outlines area of map A. C. Simplified northwest-southeast crustal section of the Sulu Sea, showing the projected locations of the drilled sites (modified from Shipboard Scientific Party, 1990d).

Sites 769 and 771 were drilled along the eastern flank of the Cagayan Ridge. At both sites, drilling reached acoustic basement and penetrated massive basaltic to andesitic coarse tuff and lapillistone (Fig. 2) mantled by thin sequences of pelagic/ hemipelagic deposits. Site 769 is on a fault block near the base of the ridge flank, at a depth of $3645 \mathrm{~m}$. About $95 \mathrm{~m}$ of pyroclastic strata were drilled at this site (Unit III), overlain by a sedimentary section $280 \mathrm{~m}$ thick. Site 771 was drilled on a large plateau higher on the ridge slope (water depth $2859 \mathrm{~m}$ ). The volcanic sequence at this site (Unit II) includes interbedded fine tuff and claystone in the upper part and several probable basalt flows in addition to the dominant coarse tuff and lapillistone. The overlying sediment section is $234 \mathrm{~m}$ thick. The volcanic sequences at both sites are interpreted as volcaniclastic apron deposits of arc volcanoes.

\section{METHODS}

Forty-five samples of pyroclastic rocks from the three Sulu Sea sites were selected for this study. Authigenic mineral assemblages were studied using a combination of thin-section microscopy, X-ray powder diffraction, and scanning electron microscopy (SEM).

$\mathrm{X}$-ray diffraction analysis was used to identify the major diagenetic minerals in each sample. Portions of each sample were first crushed and sieved to obtain a fine size fraction $(<170$ mesh, $88 \mu \mathrm{m})$ and a coarse fraction (170 to 100 mesh, 88 to $149 \mu \mathrm{m})$. The fine fraction was centrifuged to obtain the clay fraction $(<2 \mu \mathrm{m})$, which was treated with $\mathrm{MgCl}_{2}$ to saturate exchangeable cation sites with magnesium. Oriented smear slides of the clay fraction were X-rayed in air-dried and glycolated states to identify the authigenic clay minerals.

The coarse fraction for X-ray analysis was first passed through an isodynamic magnetic separator several times to obtain a nonmagnetic fraction consisting of authigenic zeolites with variable amounts of pyrogenic plagioclase and quartz. In addition, several crushed samples were hand-picked to obtain pure separates of coarse zeolite cement, zeolitized volcanic fragments, and altered plagioclase.

Diagenetic textures were studied in thin-section and through SEM examination of broken rock surfaces. An energy-dispersive X-ray analyzer (EDX) was used during the SEM studies to obtain semiquantitative elemental analyses that aided mineral identification. Thin-section billets were impregnated with dyed epoxy before sectioning to highlight primary and secondary porosity.

\section{DIAGENESIS OF THE PYROCLASTIC ROCKS: GENERAL FEATURES}

The lower Miocene pyroclastic units at all three Sulu Sea sites initially were dominated by glassy, chemically unstable pyroclasts, many of which were highly vesicular and thus possessed large surface areas in contact with pore fluids. Chemical interaction between glass and pore waters has produced extensive diagenetic changes leading to alteration of 

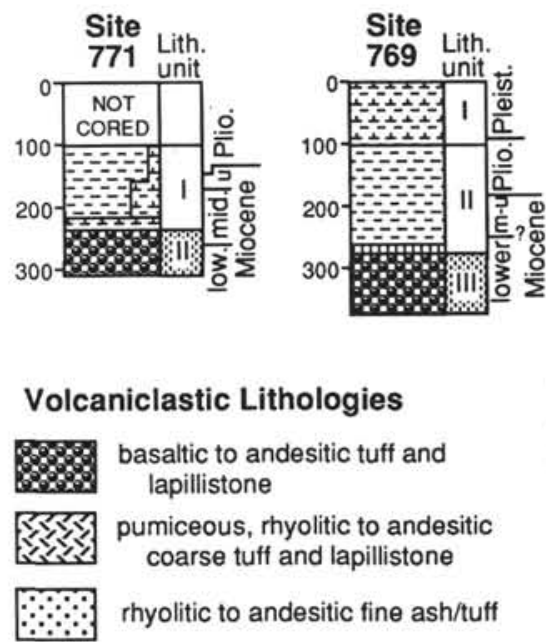

Other Lithologies

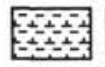

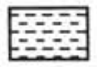

2
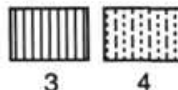

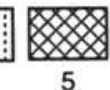

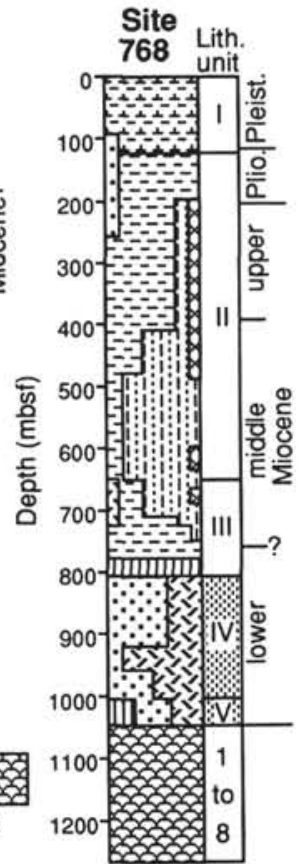

Figure 2. Simplified lithologic columns for Sites 768, 769, and 771 in the Sulu Sea, showing stratigraphic positions of volcaniclastic strata. Shaded intervals in the lithologic units columns are the object of this study. Symbols used for other lithologies are (1) marl; (2) hemipelagic sediments including clay/silt(stone); (3) pelagic brown claystone; (4) terrigenous turbidites; (5) carbonate turbidites; (6) basalt sheet flows, pillow basalt, and diabase sills (oceanic basement).

all or most of the glass, formation of authigenic clay minerals and zeolites, and lithification of the tephra into well-indurated tuff and lapillistone. Although mineralogic changes have been extensive, the original pyroclastic textures remain evident for the most part.

Although smectite is the dominant authigenic clay mineral in all the pyroclastic strata studied, differences in the silica content of the original glass played a major role in determining the zeolite assemblage formed at the different sites. In the silicic tuffs at Site 768, clinoptilolite, mordenite, and analcime are the dominant zeolites, whereas phillipsite and analcime dominate in the more mafic pyroclastics of the Cagayan Ridge sites. Despite the differences in mineralogy, similar types of diagenetic phenomena are evident in all the tuffs. Authigenic minerals have filled most primary pore space, including vesicles and intergranular pores. Two styles of glass alteration were noted in all rocks. In some shards, dissolution of glass was matched by simultaneous precipitation of authigenic clay and/or zeolites, preserving original textures such as felted or trachytic arrangements of plagioclase microlites within the altered clasts. This replacement began along free surfaces, including the outer grain boundary, the walls of vesicles, and fractures. In other clasts, an early stage of such replacement (usually by smectite) was followed by wholesale dissolution of the remaining glass, creating secondary voids within the interior of the clasts. Some of these secondary voids remain open, but most have been filled by precipitation of zeolites. Although most internal textures were obliterated by these processes, the network of vesicles within many highly vesicular clasts has remained intact, apparently the result of the earlier formation of coalescing rinds of replacement clay surrounding the closely spaced vesicles.
Pyrogenic minerals have undergone much less alteration than glassy pyroclasts. Clinopyroxene and hornblende are unaltered in nearly all samples, except for slight etching around the margins of some crystals. Alteration of plagioclase varies within single samples, with fresh unaltered crystals occurring along with others that have undergone substantial dissolution, or replacement by zeolites or clays. Substantial numbers of unaltered plagioclase crystals occur in all samples. Olivine in the tuffs at Sites 769 and 771 has been partially to completely replaced by clay and zeolites.

Diagenetic changes at the different sites are considered in more detail in the following sections.

\section{RHYOLITIC PYROCLASTIC STRATA, SITE 768 (SOUTHEAST SULU BASIN)}

\section{Primary Lithology}

The lower Miocene pyroclastic deposits of Units IV and $\mathrm{V}$ at Site 768 are poorly sorted, fine-to-coarse vitric and vitric-crystal tuff and lapillistone. Vitric clasts (now completely altered to authigenic minerals) include microvesicular pumice of the long-tube and round-vesicle varieties (Fiske, 1969), cuspate bubble-wall shards, and equant to irregularly shaped, sparsely vesicular shards. Pyrogenic crystals occur as phenocrysts within volcanic fragments and as free mineral grains. Plagioclase dominates the crystal assemblage, with minor amounts of magnetite, clinopyroxene, and hornblende; quartz is also a minor component in some samples. Volcanic lithic fragments are also common, with varied types occurring in single samples. Among the most common lithic clasts are: (1) rhyolitic clasts with felsitic or spherulitic texture; (2) nonvesicular clasts with abundant plagioclase microlites in a once-glassy groundmass replaced by zeolites or clay; (3) dark-brown to black tachylitic grains with a nearly opaque groundmass surrounding plagioclase microlites; (4) holocrystalline basalt clasts composed of plagioclase and clinopyroxene. In most of the rocks there is a continuum in grain size from coarse ash or lapilli down to silt-sized shreds of altered glass that surround and support the larger grains, so that original intergranular pores were small and irregularly shaped.

\section{Authigenic Minerals}

No fresh glass was observed in thin-sections of the samples from Units IV and V at Site 768; glass has been completely altered to various combinations of smectite, celadonite, chlorite, clinoptilolite, heulandite, mordenite, and analcime. Primary pore spaces have been filled by a complex, fine-grained aggregate of smectite, clinoptilolite, and mordenite, producing a murky, diagenetic "matrix" in which the original outlines of the altered pyroclasts are indistinct.

\section{Layer Silicates}

$\mathrm{X}$-ray diffraction analyses indicate that smectite is the dominant clay mineral in the tuffs of Site 768 , with subordinate amounts of chlorite and a $10-\AA$ layer silicate. The smectite is characteristically pale to dark brown or greenish brown, and is nonpleochroic, with first-order to low second-order birefringence. It occurs as cryptocrystalline aggregates filling vesicles and intergranular pores, and replacing glass. Smectite that fills large vesicles commonly exhibit an increase in grain size toward the center, which is occupied by aggregates of paralleloriented plates up to $40 \mu \mathrm{m}$ long, with dark greenish brown color and moderate pleochroism. Smectite within long-tube pumice clasts has a scaly or foliated texture in which clay plates show moderate to strong preferred orientation parallel to the direction of elongation of the vesicles. 
Chlorite was identified in diffraction patterns of a few samples at the top and bottom of the tuff section, and maximum peak intensity is nearly equal to that of smectite in the deepest sample. The optical properties and habit of smectite and chlorite in these rocks appear to overlap and vary from sample to sample, so the two minerals could not be distinguished in thin-section with confidence. Anomalous interference colors typical of many chlorites are absent. Diffraction patterns from chlorite-bearing samples also suggest that some mixed-layer smectite-chlorite may be present.

Minor amounts of a $10-\AA$ layer silicate were detected in diffraction patterns; this mineral has been identified in thinsection as celadonite or an iron-rich illite. It occurs with smectite replacing pumice clasts and is pale to bright bluish green, moderately pleochroic, and has second-order interference colors. Most of the distinctive bluish-green color of the tuff section at Site 768 is probably due to celadonite.

\section{Zeolites}

Clinoptilolite, heulandite, mordenite, and analcime were identified in X-ray diffraction patterns and in thin-section. Clinoptilolite is the most abundant zeolite in most of the tuffs. It occurs as aggregates of clear, euhedral to subhedral tabular crystals with prominent $(010)$ cleavage and very low relief. Clinoptilolite is most evident as pseudomorphs of glass shards of various shapes, including bubble-wall shards, round-vesicle pumice, and nonvesicular glassy fragments (PI. 1, Figs. 1 and $3)$. The tabular clinoptilolite crystals fill all or most of the interior of the shards, and are oriented at moderate to high angles to the margin of the shards (PI. 1, Fig. 1). Most such pseudomorphs formed by dissolution of glass followed by precipitation of clinoptilolite in the resulting voids, as indicated by residual cavities in the center of a few clinoptilolitelined shards. However, a few of the nonvesicular pseudomorphs probably formed by replacement. This is indicated by abundant plagioclase microlites suspended within the clinoptilolite or by a yellow or yellow-orange color retained during replacement of a palagonitized mafic glass. Clinoptilolite also occurs as fillings of a few primary intergranular pores (Pl. 1, Fig. 2).

Heulandite occurs in a few samples at the top and bottom of the tuff section, in most accompanied by clinoptilolite. Criteria that have been proposed to differentiate these closely related minerals include several chemical parameters as well as differences in their thermal behavior (see summary in Gottardi and Galli, 1985). Despite an imperfect correlation between thermal and chemical distinctions, the former was employed here. Powders were heated to $260^{\circ} \mathrm{C}$ for $4 \mathrm{hr}$ and to $500^{\circ} \mathrm{C}$ for $16 \mathrm{hr}$. The first treatment causes thermal contraction of the heulandite lattice, and the second renders it X-ray amorphous, whereas clinoptilolite survives both treatments. Clinoptilolite and heulandite can be differentiated in thinsections that are heated during preparation, because heating of clinoptilolite to temperatures of $100^{\circ}$ to $200^{\circ} \mathrm{C}$ changes its optical orientation from length-fast to length-slow, whereas heulandite remains length-fast (Boles, 1972). The sections utilized in this study were not heated beyond the temperature of this structural inversion; clinoptilolite remains length-fast, and thus heulandite could not be differentiated from it in thin-section.

Mordenite was identified in X-ray diffraction patterns of most samples, but varies greatly in abundance. Typically it is subordinate to clinoptilolite, but in a few samples is more abundant. Heavy liquids were used to obtain a relatively pure concentrate of mordenite and clinoptilolite from one such sample for X-ray analysis. The resulting diffraction data for mordenite from Site 768 are compared in Table 1 with mor- denite from rhyolitic tuffs and pitchstones. Despite significant variations in peak intensities, the good correspondence of $\mathrm{d}$-spacings confirms the identification. In thin-section and in oil-mounts of zeolite mineral separates, mordenite appears as pale-brown, radial-fibrous aggregates 10 to $70 \mu \mathrm{m}$ in diameter (PI. 1, Fig. 4), with higher relief than clinoptilolite and low first-order birefringence. The refractive indices are between 1.46 and 1.47 , significantly lower than clinoptilolite. Unlike typical mordenite, in which fibers are uniformly length-fast, the fibrous aggregates at Site 768 are uniformly length-slow. $\mathrm{X}$-ray diffraction and optical data are inconsistent with identification of this phase as one of the typically length-slow fibrous zeolites, such as natrolite or erionite, or as a fibrous silica phase. The reason for the odd optical orientation of mordenite in the tuffs at Site 768 remains enigmatic.

Mordenite formed as a void-filling phase within dissolved pumice and bubble-wall shards (Pl. 1, Fig. 4), and less commonly within primary intergranular pores. In most samples, isolated radial-fibrous aggregates occur along the margins of shard pseudomorphs filled with clinoptilolite. In the rocks in which mordenite is most abundant, glass in many pumice clasts is completely pseudomorphed by coalescing fibrous clusters of mordenite.

Analcime occurs as coarse anhedral crystals partially replacing plagioclase crystals and pumice clasts. In the latter, analcime occurs with clinoptilolite, mordenite, and smectite, and textures indicate that analcime has grown at the expense of all three other phases. The analcime in such clasts includes brownish ghosts of vesicles, suggesting that formerly smectite-filled vesicles have been replaced along with the zeolitized glass.

\section{Other authigenic minerals}

Quartz occurs in the tuffs of Site 768 as both an authigenic and pyrogenic mineral. Diagenetic quartz occurs in one Sample $(124-768 \mathrm{C}-66 \mathrm{R}-4,103 \mathrm{~cm})$ as equant, subhedral to euhedral crystals 5 to $10 \mathrm{~mm}$ in diameter lining open intergranular voids, in some cases with clinoptilolite. Very fine-grained anhedral quartz is a major constituent of nonvesicular rhyolite clasts with felsitic or spherulitic textures, but these are probably clasts derived from pre-existing rhyolite flows that devitrified prior to eruption of the tuffs. X-ray diffraction analyses show that quartz is abundant in some samples in which pyrogenic quartz and felsitic clasts are rare and in which no obvious authigenic quartz was observed in thinsection; this suggests that cryptocrystalline authigenic quartz may be intergrown with the fine-grained clays and zeolites in some rocks.

Authigenic feldspar (albite or potassium feldspar?) was observed in a few thin-sections as overgrowths on and replacements of plagioclase crystals, but is not abundant enough to be detected by X-ray analysis. Calcite or dolomite occurs as very minor, patchy replacements of all other authigenic minerals in a few samples.

\section{Diagenetic Textures and Mineral Paragenesis}

\section{Primary Pore Spaces}

Smectite fills most primary pore spaces in the tuffs at Site 768. It completely fills most vesicles, and forms much of the fine-grained "matrix" of the tuffs. In some larger intergranular pores, smectite forms only a thin rim cement coating the surrounding grains; the remainder of the pore was subsequently filled by clinoptilolite (Pl. 1, Fig. 2).

\section{Glass shards}

Bubble-wall shards and other sparsely vesicular shards are typically altered to various combinations of smectite, clinop- 


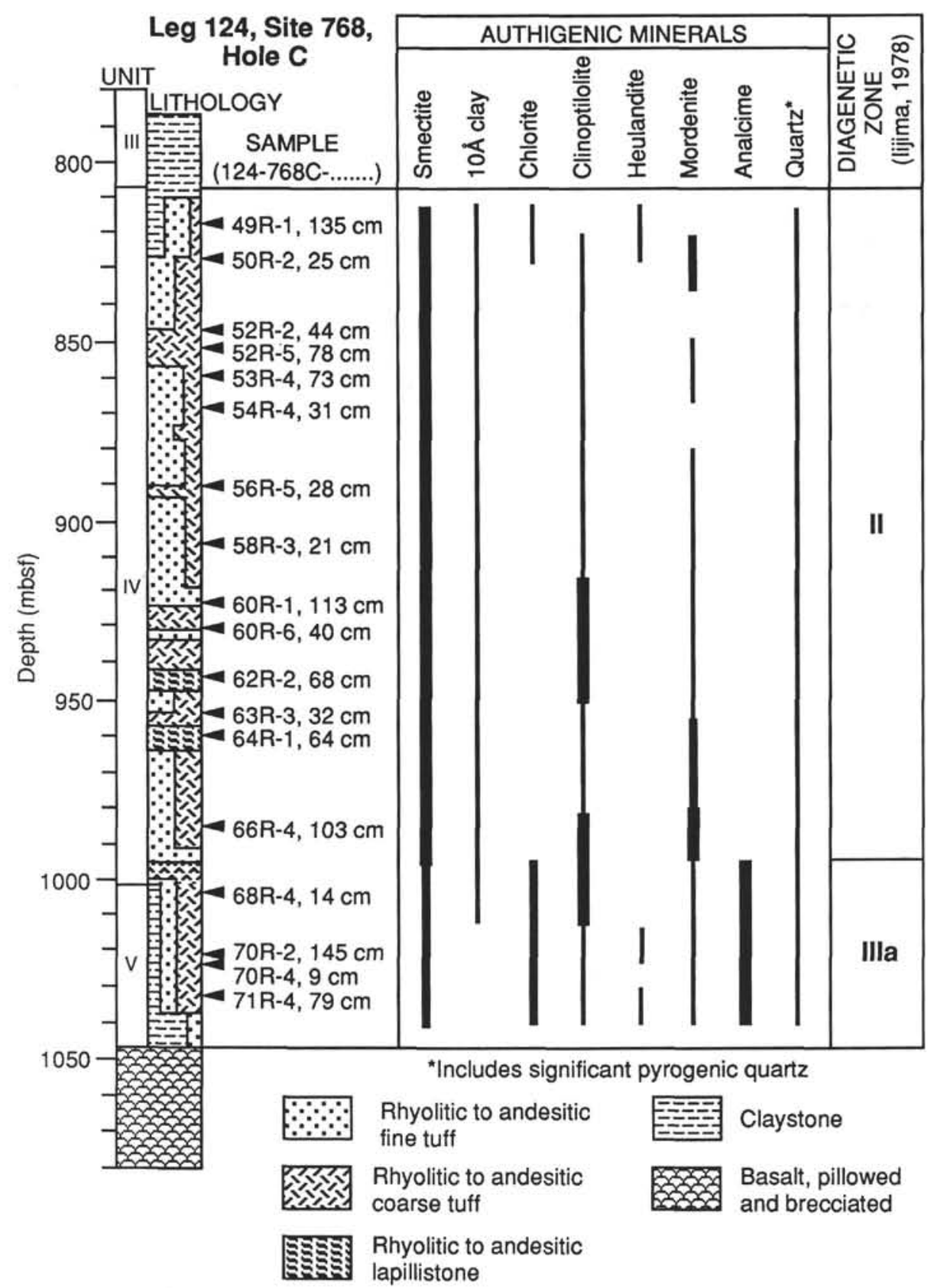

Figure 3. Lithologic column of lower Miocene pyroclastic strata (Units IV and V) at Site 768, and depth-distribution of authigenic minerals. Widths of vertical bars are roughly proportional to the abundance of the mineral in the sample. Sample number format is: core number-section number, depth in $\mathrm{cm}$ below top of section.

tilolite, and mordenite. In many shards smectite occurs as a thin rind within the outer margin of the shard; the inner margin of the smectite is very irregular (PI. 1, Fig. 1). Radial-fibrous aggregates of mordenite line parts of the inner edge of the smectite rind, but the bulk of the shard interior is occupied by tabular clinoptilolite. Based on these textures, smectite formed first as a replacement of glass around the edge of the shard. The remaining glassy interior of the shard was dissolved, and first mordenite and then clinoptilolite precipitated from solution within the secondary void. Some shards lack the irregular smectite rind, suggesting that dissolution occurred before any replacement of glass; in these examples, the outer shape of the shard was maintained by an external coating of smectite precipitated between the shards.

Some equant to irregular, nonvesicular shards are completely altered to clinoptilolite, with textures (described above) indicating that clinoptilolite crystallized simultaneously with glass dissolution.

\section{Pumice}

In round-vesicle and some long-tube pumice clasts, vesicles have been filled by smectite, whereas glass was dissolved and the resulting cavity filled by mordenite and clinoptilolite (Pl. 1, Figs. 3 and 4). However, in many long-tube pumice 
Table 1. X-ray powder diffraction data (d-spacings and relative peak intensities) for authigenic mordenite in altered tuffs from Site 768, compared to mordenite in siliceous glass and tuff from other localities.

\begin{tabular}{|c|c|c|c|c|c|}
\hline \multicolumn{2}{|c|}{$\begin{array}{c}\text { Altered tuff, } \\
124-768 \mathrm{C}-66 \mathrm{R}-4, \\
103-107 \mathrm{~cm} \\
\end{array}$} & \multicolumn{2}{|c|}{$\begin{array}{l}\text { Altered tuff in Esmeralda } \\
\text { "Formation", Nevada } \\
\text { (Moiola, 1964) }\end{array}$} & \multicolumn{2}{|c|}{$\begin{array}{c}\text { Altered pitchstone, } \\
\text { Isle of Mull, Scotland } \\
\text { (Harris and Brindley, 1954) }\end{array}$} \\
\hline$d(\hat{A})$ & 1 & $\mathrm{~d}(\dot{A})$ & 1 & $d(A)$ & 1 \\
\hline 13.51 & 1 & 13.4 & 6 & 13.7 & 5 \\
\hline $8.98^{\circ}$ & (7) & 9.10 & 9 & 9.10 & 9 \\
\hline 6.56 & 3 & 6.60 & 9 & 6.61 & 9 \\
\hline 6.38 & 1 & & & 6.38 & 4 \\
\hline 6.04 & 1 & 6.10 & 2 & 6.10 & 5 \\
\hline 5.79 & 1 & 5.79 & 5 & 5.79 & 5 \\
\hline 5.06 & 2 & & & 5.03 & 1 \\
\hline 4.87 & 1 & 4.89 & 1 & 4.87 & 2 \\
\hline 4.52 & 3 & 4.54 & 6 & 4.53 & 8 \\
\hline 4.13 & 1 & & & 4.14 & 3 \\
\hline $3.99^{\circ}$ & (9) & 4.00 & 10 & 4.00 & 9 \\
\hline 3.83 & 2 & 3.86 & 5 & 3.84 & 6 \\
\hline $3.76 \#$ & (2) & 3.78 & 4 & 3.76 & 2 \\
\hline $3.62 \#$ & 1 & & & 3.62 & 1 \\
\hline $3.56^{*}$ & (2) & & & 3.56 & 1 \\
\hline 3.48 & 10 & 3.48 & 10 & 3.48 & 10 \\
\hline \multirow[t]{2}{*}{$3.39^{*}$} & (7) & 3.39 & 5 & 3.39 & 9 \\
\hline & & & & 3.31 & 1 \\
\hline 3.22 & 7 & 3.22 & 10 & 3.22 & 10 \\
\hline $3.12 \#$ & (2) & 3.10 & 1 & 3.10 & 2 \\
\hline $2.97^{\circ}$ & (5) & 2.94 & 3 & 2.95 & 2 \\
\hline 2.89 & 3 & 2.89 & 6 & 2.90 & 6 \\
\hline 2.73 & 3 & 2.72 & 1 & 2.74 & 1 \\
\hline \multirow[t]{2}{*}{2.70} & 1 & 2.70 & 2 & 2.70 & 3 \\
\hline & & & & 2.64 & 1 \\
\hline 2.56 & 2 & & & 2.56 & 4 \\
\hline $2.52^{\circ}$ & (3) & 2.51 & 6 & 2.52 & 5 \\
\hline
\end{tabular}

Notes: ${ }^{-}=$coincident with diffraction peak from clinoptilolite in sample

$\#$ = coincident with diffraction peak from plagioclase in sample

() = relative intensity of combined diffraction peak

clasts glass was replaced by smectite and celadonite, and smectite also fills the vesicles, so that these clasts are almost completely altered to clays. Many such clasts have been highly flattened parallel to bedding during compaction.

\section{Depth Distribution of Diagenetic Changes and Mineral Paragenesis}

The depth distributions of the major authigenic minerals in Units IV and V at Site 768 are shown in Figure 3. Smectite occurs throughout the section, but decreases in abundance in the lower $60 \mathrm{~m}$ of the pyroclastic section, coincident with the appearance of chlorite. The $10-\AA$ clay mineral (celadonite?) also disappears in the lowermost part of the section. These relationships suggest that chlorite formed from pre-existing

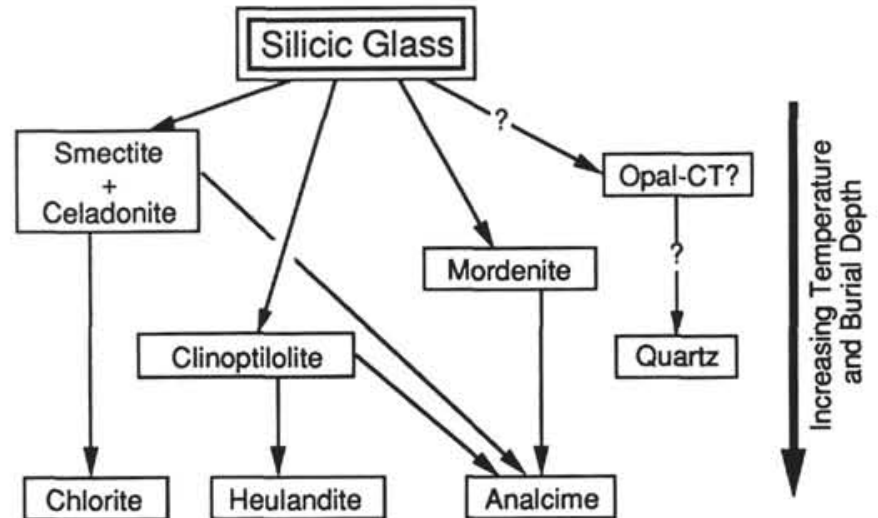

Figure 4. Inferred paragenetic sequence of authigenic minerals in silicic tuffs in Units IV and V, Site 768.

smectite and celadonite. Among the zeolites, clinoptilolite occurs through all but the uppermost part of the pyroclastic section, accompanied in most samples by mordenite. Analcime occurs only in the lower $60 \mathrm{~m}$ of the section, coincident with the sporadic appearance of heulandite, and with decreasing amounts of clinoptilolite and mordenite. These distributions support the textural observations suggesting that analcime formed from pre-existing mordenite and clinoptilolite.

Based on the depth distributions of authigenic minerals, two diagenetic zones can be recognized in the lower Miocene pyroclastic deposits at Site 768. These zones correspond closely to the vertical diagenetic zonation described by Iijima (1978) from thick Miocene marine silicic tuff sequences in Japan. Accordingly, Iijima's zonal terminology is used here. Most of the pyroclastic section at Site 768, from the top of Unit IV to a depth of 990 to $1000 \mathrm{~m}$, corresponds to Zone II, characterized by alteration of silicic glass to form clinoptilolite, mordenite, and smectite. The lower part of the pyroclastic section corresponds to Zone IIIa of the Japanese deposits, in which analcime is formed from clinoptilolite and mordenite, some clinoptilolite is converted to heulandite, and smectite is gradually replaced by chlorite and a $15-\AA$ to $14-\AA$ mixed-layer clay. Zone I, the shallowest diagenetic zone of Iijima (1978), is characterized by silicic glass partly altered to smectite and opal-A or opal-CT, with zeolites absent. The boundary between Zones I and II lies above the lower Miocene tuff section at Site 768.

The paragenetic sequence of authigenic minerals produced by alteration of silicic glass in Units IV and V is summarized in Figure 4. The relationships are inferred from the textural data and depth distribution of phases outlined above. Hydration and leaching of silicic glass resulted first in the formation of smectite (with lesser celadonite) as replacement of glass and as void-fills. Mordenite was the earliest zeolite formed, followed by clinoptilolite. The pathway leading from silicic glass to opal-CT to quartz is conjectural, based on the possibility that significant diagenetic quartz is present and the common occurrence of opal-CT as a metastable early silica phase in altered tuffs. With increasing burial depth and temperature in the lowermost part of the pyroclastic section, smectite was partially replaced by chlorite, and heulandite and analcime formed at the expense of clinoptilolite, mordenite, and smectite.

\section{Diagenetic Conditions}

Authigenic mineral assemblages in volcaniclastic deposits vary depending on the composition of the starting materials, temperature (related to burial depth and heat flow), pressure, 
fluid composition, and other factors (Surdam and Boles, 1979). There appears to be no large-scale vertical compositional variation within the pyroclastic deposits in Units IV and $\mathrm{V}$ at Site 768 , indicating that the observed vertical zonation of diagenetic minerals most likely resulted from variation in burial depth. Diagenetic studies of subsurface Neogene tuff sequences in Japan (Iijima and Utada, 1971; Iijima, 1978) suggest that such vertical zonations in silicic tuffs (exclusive of saline lake deposits) are related primarily to the increase in temperature with depth. Temperature measurements in drill holes through the altered marine tuff sequences in Japan indicate present temperatures of $40^{\circ}$ to $49^{\circ} \mathrm{C}$ for the top of the clinoptilolite/mordenite zone (Zone II) and $84^{\circ}$ to $91^{\circ} \mathrm{C}$ for the base, defined by the formation of analcime from clinoptilolite and mordenite (Zone II/Zone III boundary). The breakdown of analcime to albite at greater depth in the section occurs at temperatures of $120^{\circ}$ to $125^{\circ} \mathrm{C}$. Iijima and Utada (1971) believe that zeolitic diagenesis is currently in progress at these sites, in which case these measurements represent actual temperatures of the mineral transformations.

No temperature measurements were obtained during drilling at Site 768 , but a heat-flow measurement of $108 \mathrm{~mW} / \mathrm{m}^{2}$ obtained prior to drilling (Vollbrecht and Kudrass, 1990) yields an estimated temperature gradient of $98^{\circ} \mathrm{C} / \mathrm{km}$ (von Breymann et al., this volume). Using this gradient, the estimated present temperature of the Zone II/Zone III boundary at Site 768 is $98^{\circ} \mathrm{C}$, slightly higher than the range of temperatures measured in the Japanese oil-field studies. However, measured heat-flow values in the southeast Sulu Basin vary widely, from 54 to $154 \mathrm{~mW} / \mathrm{m}^{2}$ (Vollbrecht and Kudrass, $1990)$, so the present temperature at this boundary could be either higher or lower than the temperature estimated above. Based on the temperature data from the Japanese tuff sequences, it appears most likely that alteration of the tuffs at Site 768 took place during burial at temperatures between $50^{\circ}$ and $100^{\circ} \mathrm{C}$.

The presence of chlorite and heulandite at the top of Unit IV at Site 768 suggests that temperature is not the only factor controlling the vertical distribution of the diagenetic minerals. Although the composition of the tuff does not vary significantly, the uppermost tuffs containing chlorite and heulandite are interbedded with and overlain by claystone. Chemical interaction of pore waters with both tuff and claystone may have resulted in a significantly different pore-water chemistry at the top of Unit IV, resulting in a slightly different alkali zeolite-clay assemblage in this interval compared to the bulk of the tuff.

\section{BASALTIC PYROCLASTIC STRATA, SITES 769 AND 771 (CAGAYAN RIDGE)}

\section{Primary Lithology}

The dominant lithologies in the lower Miocene pyroclastic rocks at Sites 769 and 771 are massive, unstratified coarse tuff and lapillistone (Fig. 2). In most of these deposits the pyroclasts are moderately sorted and loosely packed, with no primary matrix of finer particles, so that intergranular pores were large and initial permeability was quite high. In a few samples, however, the larger pyroclasts are surrounded by a matrix of silt-sized volcanic grains and broken phenocrysts. At Site 769 unstratified coarse deposits make up the entire pyroclastic section of Unit III. At Site 771 similar deposits are overlain by a thinner sequence of thin, graded coarse to fine tuffs interbedded with marine claystone, and thin basalt flows occur at the top and base of the volcanic sequence (Unit II).
Pyroclasts in the tuff and lapillistone fall into three main groups. The dominant pyroclasts $(50 \%$ to $90 \%)$ are dense to highly vesicular vitric clasts that are ovoid to irregular in shape. In unaltered clasts the glass is clear, pale-brown sideromelane, and plagioclase microlites are sparse to absent. Most of the round to ovoid vesicles are less than $200 \mu \mathrm{m}$ in diameter, and breached vesicles form embayments along the clast margins. The second pyroclast type is less abundant ( $10 \%$ to $50 \%$ ), and consists of dark-brown to black, nearly opaque tachylite grains with abundant plagioclase and pyroxene microlites, and sparse larger vesicles. The least-abundant clast type $(10 \%$ to $15 \%)$ includes nonvesicular to sparsely vesicular microlitic clasts in which abundant plagioclase microlites are set in clear or pale-brown sideromelane glass. Distinctions between these types are not sharp, and most are probably co-magmatic. Phenocrysts of plagioclase, clinopyroxene, magnetite, and olivine occur in all three types but are less abundant in the vesicular vitric clasts. Phenocryst phases occurring as free crystals form a minor component of the tuff and lapillistone.

\section{Authigenic Minerals}

Alteration of the basaltic tuff and lapillistone at Sites 769 and 771 has been pervasive, and only minor amounts of fresh glass remain in a few samples. The major products of diagenesis are smectite and phillipsite, which occur as replacements of glass and as void-filling phases, and analcime, which replaces glass, plagioclase, and olivine in some rocks. Calcite occurs as a late void-filling phase in a few samples.

\section{Smectite}

Smectite is the only clay mineral identified by X-ray diffraction analyses and is the dominant authigenic mineral by volume, imparting a dull green color to the rocks. It fills vesicles, forms a rim cement surrounding clasts, and is a major alteration product of basaltic glass. In thin-section, smectite is very fine-grained to cryptocrystalline, ranging from yellow brown to greenish brown in color, and is typically nonpleochroic, with low first-order birefringence. The smectite is a magnesium and iron-rich trioctahedral saponite, based on X-ray analyses of randomly-oriented powder mounts (060 diffraction peak at $1.53 \AA$ ), and EDX spectra showing $\mathrm{Si}, \mathrm{Al}$, $\mathrm{Mg}$, and $\mathrm{Fe}$ as the major cations; minor $\mathrm{Ca}$ is detectable is a few instances. Smectites replacing glass and those occurring as cements are similar in composition.

\section{Zeolites}

Phillipsite is the dominant zeolite in the altered tuffs, occurring as the most abundant intergranular cement in the tuffs lacking matrix, and partially replacing vitric clasts. Phillipsite occurs in habits ranging from radial-fibrous to coarsely prismatic. EDX analyses show that $\mathrm{K}$ exceeds $\mathrm{Na}$ in abundance, and that $\mathrm{Ca}$ is undetectable in most grains. Analcime does not occur as a void-filling phase, but replaces vitric clasts, plagioclase, and olivine.

\section{Diagenetic Textures and Mineral Paragenesis}

Authigenic minerals in the basaltic tuff and lapillistone of Sites 769 and 771 occur as replacements of glass and pyrogenic minerals, and as fillings of primary and secondary voids. Textures of minerals filling pores and replacing vesicular sideromelane clasts provide the main clues to the paragenetic sequence of authigenic minerals. Clinopyroxene phenocrysts are unaltered except for some slight dissolution around the margins, but olivine and plagioclase show variable and distinctive suites of alteration products. 


\section{Primary Pore Spaces}

Intergranular pores have been almost completely filled in most samples by two main cements: an early smectite rim cement succeeded by radial aggregates of phillipsite (PI. 2).

\section{Smectite Rim Cement}

In rocks lacking a primary fine tuff matrix, the smectite rim cement forms even, isopachous coatings around all grains except at points of contact between adjacent grains (PI. 2, Figs. 1 and 2). The thickness of the coating is fairly uniform within individual samples but varies from sample to sample. At Site 769 , the clay rims vary from 10 to $70 \mu \mathrm{m}$ in thickness, but there is no systematic pattern to the thickness variations with depth. At Site 771 the clay coatings are much thinner (2 to $30 \mu \mathrm{m}$ ), and much more irregular in thickness in individual samples. Only a small volume of the original intergranular pore space was filled by precipitation of the smectite rim cement.

In tuffs with a primary matrix of fine altered glass shards and crystals, smectite completely fills most of the small voids between the fine clasts, producing a murky diagenetic "matrix" in which the distinction between altered shards and cement is difficult. However, even in these poorly sorted tuffs there are some larger open voids lined by well-defined clay rims. Such poorly sorted tuffs are more common at Site 771 than at Site 769.

The clay coatings are dark olive-green in hand-specimen, and brown to greenish brown in thin-section. In some samples the clay rims exhibit concentric color zoning, from nearly colorless adjacent to the grain surface to strongly colored adjacent to the later phillipsite cement. The pale colored clay shows low first-order interference colors, which are masked in the more strongly-colored clay by the mineral color. The shape and orientation of clay crystallites within the smectite rim cement cannot be resolved in thin-sections or with the SEM. Fractures across the clay coats have a slightly hackly texture (Pl. 3, Fig. 1), and their outer surfaces have a finely pustular morphology (PI. 3, Figs. 2 and 3). The clay within the coatings exhibits a strong preferred optical orientation, with the fast vibration direction perpendicular to the grain boundary. This suggests that the smectite consists of fine fibers oriented perpendicular to the underlying grain and elongate on the $c$ crystallographic axis; this is a common habit for saponite (Phillips and Griffen, 1981).

Smectite similar to the clay rim cement lines most vesicles in the altered sideromelane clasts, and in most it is the only authigenic mineral present. In partially-filled vesicles the free surface of the smectite exhibits a web-like or honeycomb morphology (PI. 3, Figs. 4 and 5) unlike the surface of the clay rim cement, but more typical for void-filling smectite (Wilson and Pittman, 1977; Welton, 1984).

\section{Phillipsite Cement}

Pore spaces remaining open after precipitation of the smectite rim cement have been almost completely filled in most samples by radiating aggregates of phillipsite that nucleated on isolated points on the earlier clay rim surface (Pls. 2 and 3). Void-filling phillipsite occurs primarily in intergranular pores, but also forms a second-stage filling of some larger smectite-lined vesicles. In all samples the phillipsite aggregates exhibit a change in habit from fibrous in the center to prismatic in the outer part (Pl. 2, Fig. 1 and Pl. 4, Figs. 1 to 3). The fibrous centers of the phillipsite aggregates are clear to translucent in hand-sample, and were incorrectly identified as chalcedony in shipboard descriptions of the tuffs (Shipboard Scientific Party, 1990b). The radius of the fibrous centers varies from 100 to $1000 \mu \mathrm{m}$ at Site 769 , but is much less at Site 771 (mostly less than $100 \mu \mathrm{m}$ ). The prismatic outer portions of the aggregates are typically milky white and opaque, with prisms less than $10 \mu \mathrm{m}$ in width and several hundred $\mathrm{mm}$ in length. The prisms become coarser toward the center of the pores (PI. 4, Fig. 4).

The fibrous and prismatic portions of the radial aggregates differ in optical orientation as well as grain size, but EDX spectra from both forms in single aggregates are identical, and hand-picked cement separates including both morphologies yield only phillipsite diffraction patterns. The transition from fibrous to prismatic forms is abrupt, and marked by a thin fibrous zone that is brown in plane-polarized light and has higher relief than the surrounding clear phillipsite ( $\mathrm{Pl}$. 4, Fig. $1)$. The fibrous centers have higher birefringence (first-order white) than the prismatic form (Pl. 4, Fig. 2). The fibers are uniformly length-slow, with extinction angles less than $10^{\circ}$, whereas the prisms have higher extinction angles and both length-slow and length-fast orientations. Where open space remains in the center of pores, the euhedral phillipsite prisms can be seen with the SEM to have square to cruciform cross sections (Pl. 4, Figs. 4 and 5). This common habit of coarse phillipsite is formed by four-fold and eight-fold interpenetration twins, elongate on the $a$ crystallographic axis (Gottardi and Galli, 1985), and twin boundaries can be seen in thinsection where the prisms have been cut at a high angle to the $a$ axis. In contrast, the length-slow orientation and low extinction angle of the fibrous phillipsite suggest that the fibers are elongate on the $c$ crystallographic axis. Radial-fibrous aggregates of length-slow phillipsite have been described in altered silicic tuffs by Sheppard and Gude (1969). Honnorez (1978) and Ijima and Harada (1969) noted the occurrence of radial-fibrous phillipsite as void fills in mafic palagonite tuffs, but did not note its optical orientation.

The cause of this change in phillipsite crystal form and orientation is unknown, but may be related to changes in the composition of pore waters that resulted in a decrease in the overall rate of phillipsite precipitation and differentially affected the rate of crystal growth along crystallographic axes. Alternatively, the fibrous phillipsite may have formed by replacement of an early radial-fibrous mineral whose structure controlled the orientation of the replacement phillipsite.

In the tuffs at Site 771 , pore space remaining after phillipsite precipitation has been filled, in a few samples, by aggregates of randomly oriented coarse clay. The clay is pale green, nonpleochroic, with second-order interference colors. The green clay has not been isolated for X-ray diffraction analysis, but it could be either a coarse smectite or a chlorite.

\section{Vitric Clasts}

Alteration of sideromelane glass is complete in most of the tuffs at Sites 769 and 771 . Alteration processes included formation of palagonite; replacement by smectite, phillipsite, and analcime; partial dissolution of clast interiors to form secondary voids; and partial to complete filling of secondary voids by coarse platy clay, phillipsite, and rare analcime. Optical identification of phillipsite and analcime within vitric clasts was verified by X-ray diffraction analysis of handpicked separates of zeolitized clasts from several samples.

Palagonite, the first stage of alteration of sideromelane glass, is preserved in parts of the tuff. The term palagonite is used here to refer to cryptocrystalline or rarely fibrous, isotropic to slightly birefringent alteration products of sideromelane. In samples with residual fresh glass, bright-yellow palagonite occurs in the outer part of shards with cores of fresh glass. In the more common tuffs with no residual glass, the palagonite is dull yellow-brown in color and is partially 
A

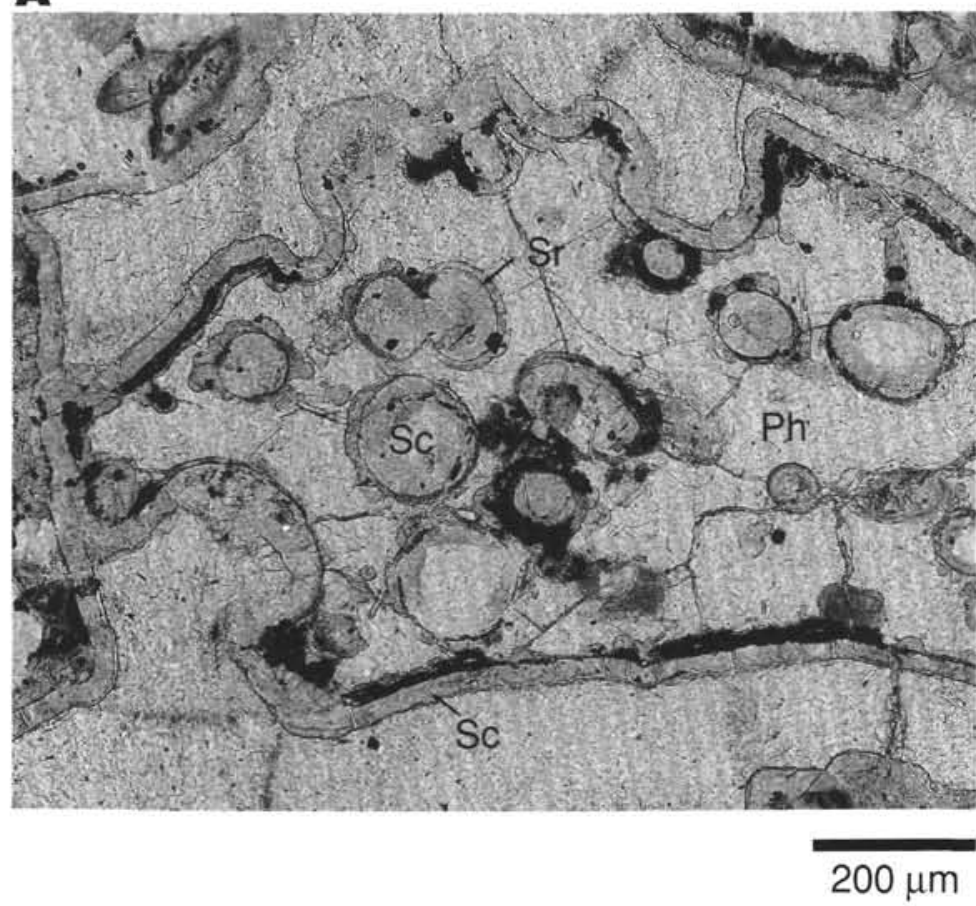

B

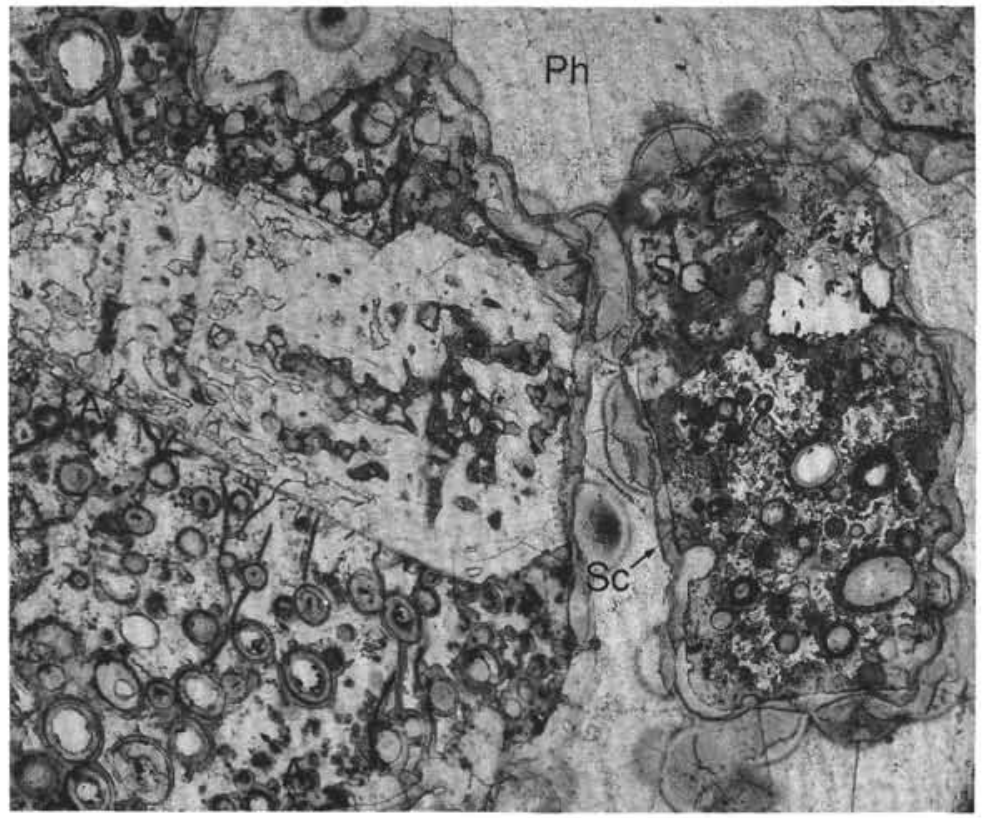

$500 \mu \mathrm{m}$

Figure 5. Thin-section photomicrographs of zeolitized vitric clasts in basaltic tuffs of Unit III, Site 769. A. Vesicular clast with most of the clast interior now occupied by coarse phillipsite $(\mathrm{Ph})$. Smectite rim cement $(\mathrm{Sc})$ coats the exterior of the clast and fills vesicles. Thin discontinuous layers of replacement smectite (Sr) outline vesicle walls and part of the clast margin. Phillipsite is interpreted as filling a secondary void formed by dissolution of the interior of the clast. A very thin coating of platy, birefringent clay (not evident in the photograph) precipitated around the edges of the cavity prior to crystallization of phillipsite. Pores surrounding the clast are filled by radial-fibrous to radial-prismatic phillipsite. Plane-polarized light, Sample 124-769C-3R-1, 39-42 cm. B. Highly vesicular vitric clasts with interiors largely replaced by clear analcime (A). Vesicles are lined by dark smectite. Large patches of replacement smectite (Sr) remain in the clast on the right, and numerous clay inclusions are scattered through the analcime. The plagioclase phenocryst in the larger clast is partially replaced by analcime in irregular patches, and contains wormy dark patches of smectite interpreted as altered glass inclusions. Smectite rim cement (Sc) and radial phillipsite aggregates (Ph) fill intergranular pores. Plane-polarized light, Sample 124-769C-8R-6, 105-108 cm. 


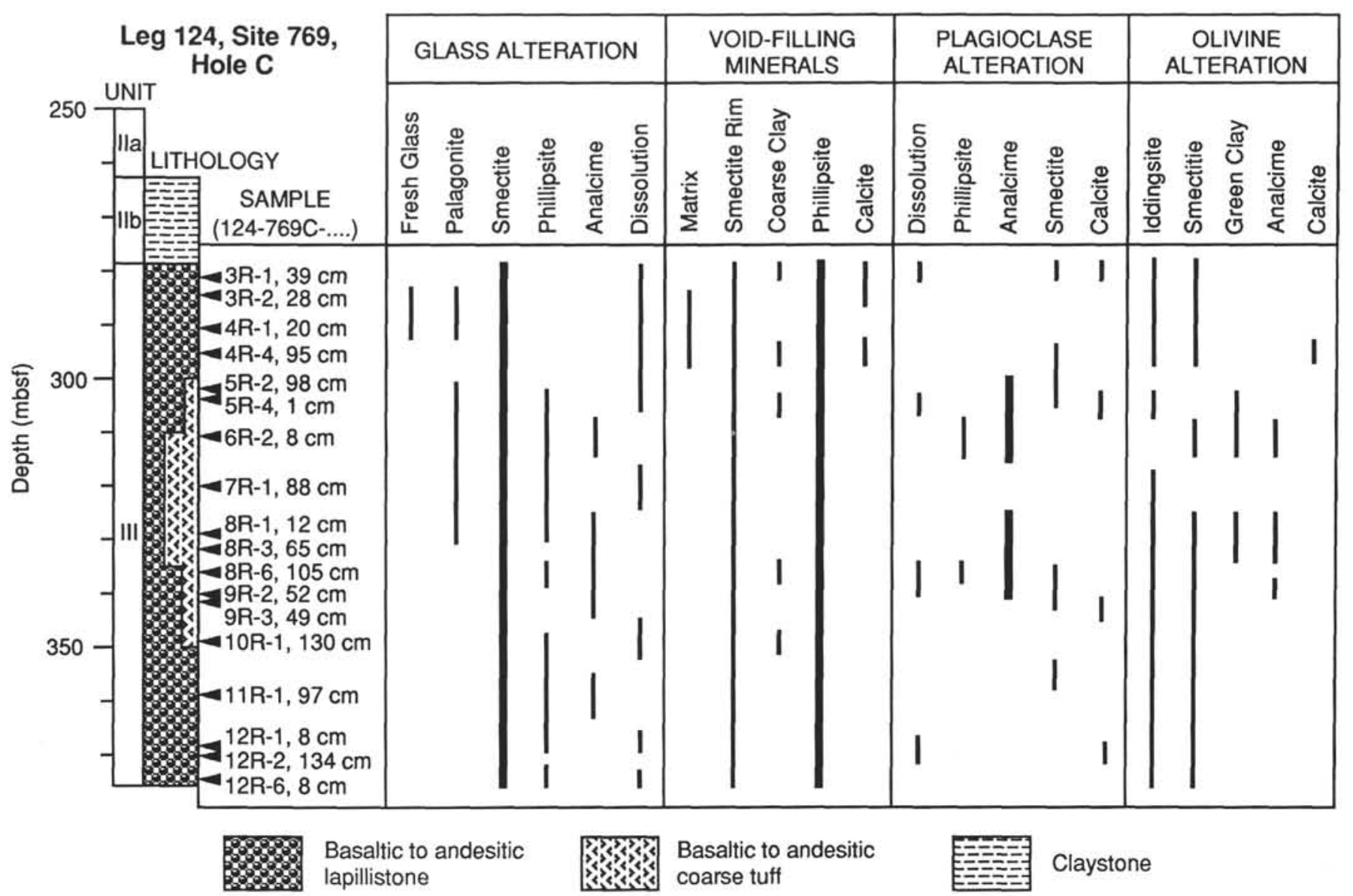

Figure 6. Lithologic section of early Miocene pyroclastic strata (Unit III) at Site 769, and depth-distribution of authigenic minerals. Widths of vertical bars are roughly proportional to abundance of mineral in sample.

replaced by birefringent smectite. Published X-ray diffraction and transmission electron microscopy studies of palagonite (summarized by Fisher and Schminke, 1984, pp. 314-328) indicate that it consists of hydrated glass partially to completely replaced by poorly crystalline submicroscopic smectite, with illite and mixed layer smectite-illite reported in some cases.

Smectite is the most abundant replacement mineral in the altered vitric clasts (Pl. 2, Fig. 1; Pl. 3, Fig. 1; Pl. 4, Figs. 1 and $3)$. It occurs as extremely fine-grained granular aggregates with very low birefringence, and as small radial clusters and layers of more birefringent, length-fast fibers several micrometers in length. Layers of fibrous smectite surround many vesicles and occur along the margins of grains and adjacent to fractures. Isolated clusters of radial clay fibers appear to have nucleated on similar surfaces. In samples with residual palagonite, both fibrous and granular smectite can be seen in individual clasts, replacing palagonite.

In parts of the tuff sections, smectite replacement of vitric clasts was followed by dissolution of the grain interior (probably residual glass or palagonite) to produce secondary voids. Thin layers of finely fibrous replacement smectite along the grain margins and surrounding smectite-filled vesicles survived dissolution and formed the walls of the secondary voids. In clasts with closely-spaced small clay-filled vesicles, the layers of replacement clay bridge the gaps between vesicle walls, linking together and supporting the clay amygdules (PI. 3, Fig. 6). Some voids remain open and are evident in thin-sections of samples impregnated with dyed epoxy and upon examination of broken sample surfaces with a stereomicroscope or SEM. Many secondary pores have been infilled by the precipitation of clay and phillipsite; both open and filled voids typically occur in single samples. Calcite occurs as a minor filling of secondary pores in a few samples from Site 769. Dissolution effects are more evident in the tuffs of Site 769 than at Site 771, and most secondary voids at the latter site are unfilled.

The earlier of these void-fills is a platy clay found in the secondary pores only at Site 769 (Pl. 5, Fig. 1). It forms an isopachous layer a few micrometers thick lining the cavities, consisting of loosely aggregated clay flakes oriented normal to the cavity walls. The clay plates are pale yellow-green, length slow, and have upper first-order birefringence, significantly higher than the replacement clay or smectite rim cement. Similar coarse clay occurs in the same samples as a secondstage fill of vesicles, and was found very locally in intergranular voids sandwiched between the earlier smectite rim cement and the later radial phillipsite cement. Although the platy clay could not be isolated for X-ray diffraction analysis, other data suggest it is a smectite. EDX analyses of platy clay surfaces lining vesicles and secondary voids show elemental spectra similar to those of the smectite rim cement and the replacement smectite, with $\mathrm{Mg}$ exceeding Fe. The surfaces of the platy clay layers have a web-like morphology (Pl. 5, Figs. 1 and 2), and thin clay fibers bridge gaps between closelyspaced clay-coated vesicles (PI. 5, Figs. 3 and 4); these textures are also typical of void-filling smectites (Wilson and Pittman, 1977, Welton, 1984). 
The interiors of many vitric clasts are now occupied by phillipsite or analcime (Fig. 5). Earlier fibrous replacement clay usually remains around the margins of these clasts, and commonly separates the zeolites from the clay-filled vesicles (Fig. 5A). Phillipsite occurs within the clasts as coarse prismatic to blocky crystals (Fig. 5A), or as radial aggregates. Analcime occurs as coarse, anhedral, isotropic crystals (Fig. 5B). Phillipsite occurs both as fillings of secondary voids within the clasts and as replacements; analcime occurs almost exclusively as a replacement. Textural criteria cannot differentiate between void-filling and replacement origins in all cases, but the following criteria are used to infer a void-filling origin for phillipsite:

1. Incomplete filling of the secondary void;

2. Presence of a thin layer of pore-lining platy clay separating the void-filling phillipsite from the earlier replacement clay;

3. Contacts between phillipsite and replacement clay are consistently sharp, never gradational;

4. Radial-fibrous to radial-prismatic habit, identical to the intergranular void-fills (uncommon; most void-filling phillipsite is coarsely prismatic);

5. Lack of dispersed microlites or other inclusions within the phillipsite.

A replacement origin for analcime and some phillipsite is inferred from the following textural criteria:

1. Presence of numerous dispersed microlites or irregular patches of granular replacement clay within the zeolite;

2 . Gradational boundary between the zeolite and replacement clay (but sharp boundaries are also common);

3. Absence of open secondary voids within the sample (but both dissolution and zeolite replacement occur together in a few samples).

Replacement phillipsite and analcime may occur together in the same clast, but textural criteria do not reveal the relative timing of their formation. It is not clear whether the zeolites directly replaced palagonite or whether an earlier finely granular replacement smectite was selectively replaced, leaving the more fibrous replacement smectite unaltered.

\section{Plagioclase Alteration}

Plagioclase phenocrysts and free crystals exhibit variable alteration effects. In some samples all plagioclase crystals appear fresh, but in most, one or more types of alteration have occurred. Some crystals are partially dissolved, and others are partially replaced by clay, analcime, phillipsite, or calcite. Optical identification of analcime and phillipsite was verified by X-ray diffraction analyses of hand-picked plagioclase separates from several samples at Site 769.

Dissolution of plagioclase crystals is common in the tuffs; its effects range from small angular secondary voids within otherwise fresh crystals, to complete dissolution of the plagioclase grain. Minor to extensive replacement of plagioclase by clear, isotropic analcime is also common, with analcime occurring as highly irregular, ragged patches around the edges and in the interior of the crystal (Fig. 5B). Phillipsite occurs as a replacement around the edges of plagioclase crystals in a few samples and is coarse and anhedral in habit.

Many plagioclase crystals contain numerous well-defined blebs of brown to green smectite with smooth, rounded margins (Fig. 5B). These blebs are interpreted as smectite replacements of glass inclusions, on the basis of the presence of unaltered glass inclusions in plagioclase grains in samples with residual fresh glass. However, in some plagioclase crystals, the clay has also replaced some of the adjacent plagioclase, mostly along cleavage planes.

\section{Olivine Alteration}

Euhedral to subhedral olivine phenocrysts are completely altered in the tuff at Site 769, but cores of some altered crystals remain fresh at Site 771 . The most common alteration products of olivine are orange to brown "iddingsite" (a fine-grained aggregate of goethite, smectite, and other phyllosilicates) and a pale brown to green, nonpleochroic clay similar in color and optical properties to smectite in the surrounding rock. The two phases may occur alone, or together in single pseudomorphs, in which case the boundaries between the two are ragged and suggest that the smectite has replaced earlier "iddingsite."

In several samples from Site 769, "iddingsite"' and smectite are accompanied in some olivine pseudomorphs by a strongly pleochroic (pale yellow to bright green) phyllosilicate mineral with anomalous yellow-green interference colors, possibly nontronite. Analcime occurs as partial replacements of olivine pseudomorphs containing any or all of the preceding phases in samples from both sites, and minor calcite occurs with iddingsite and smectite at Site 769.

\section{Depth Distribution of Diagenetic Changes and Mineral Paragenesis}

The distributions with depth of authigenic minerals in the lower Miocene tuffs at Sites 769 and 771 are shown in Figures 6 and 7, respectively. In general, variations in alteration patterns with depth are minimal. Cementation phenomena do not vary significantly with depth, and dissolved vitric grains and plagioclase occur sporadically throughout the drilled sections. The major stratigraphic changes concern the extent and type of alteration of glass and plagioclase.

Remnants of apparently fresh glass occur only in the upper 10 to $20 \mathrm{~m}$ of the tuff sections at both sites. Palagonite and smectite are the main alteration products of glass in these intervals. At Site 769, glass relics are found within a zone in which a matrix of altered fine ash and clay cement is present, and at Site 771 the glass-bearing tuff occurs interbedded with fine tuff and claystone. These occurrences suggest that glass preservation might be partly related to low permeability and resulting decreased fluid movement following early clay cementation in the matrix-bearing tuffs. On the other hand, matrix-rich tuffs with no residual glass are common in the deeper part of the section at Site 771, suggesting that preservation of glass at the top of the tuff sections may also be related to lower temperature, or a difference in pore-fluid composition resulting from contact with the overlying claystone and marl sequences.

Some palagonite survives below the fresh glass zone at Site 769 , but at both sites the alteration of vitric clasts becomes more complex at depths of 20 to $40 \mathrm{~m}$ below the top of the tuff units. At these depths, replacement of vitric clasts by phillipsite begins or becomes more pronounced, and analcime first occurs as replacements in vitric clasts and plagioclase. Replacement phillipsite and analcime persist sporadically to the bottom of the holes.

Alteration of basaltic glass has produced the greatest volume of diagenetic minerals at Sites 769 and 771. Leaching and wholesale dissolution of glass resulted in precipitation of smectite and phillipsite cements, and glass has been replaced by smectite, phillipsite, and analcime. Textural relationships and depth distributions yield the inferred paragenetic sequence shown in Figure 8 for these minerals. Initial alteration of sideromelane to palagonite and then to smectite (saponite) 


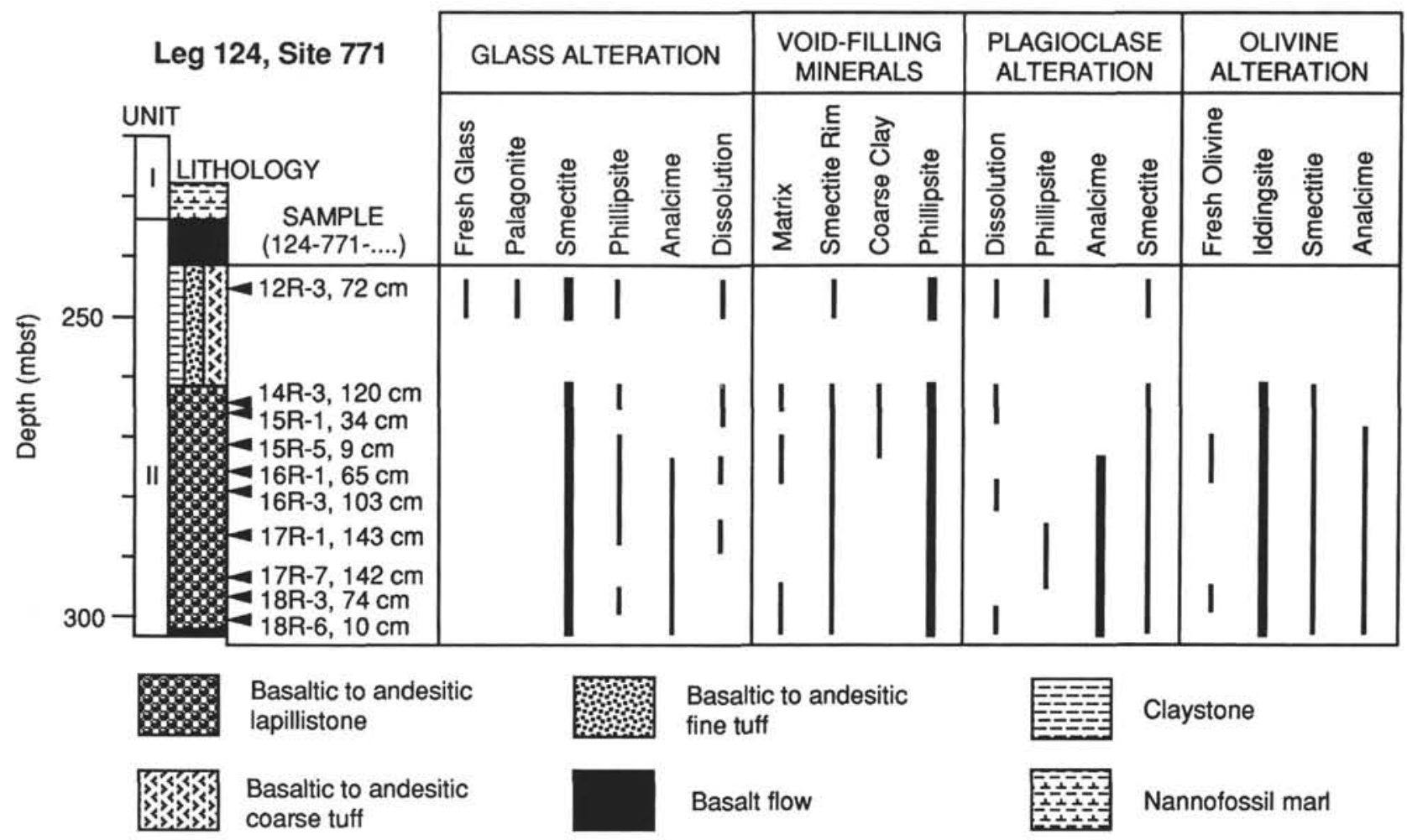

Figure 7. Lithologic section of early Miocene pyroclastic strata (Unit II) at Site 771, and depth-distribution of authigenic minerals. Widths of vertical bars are roughly proportional to abundance of mineral in sample.

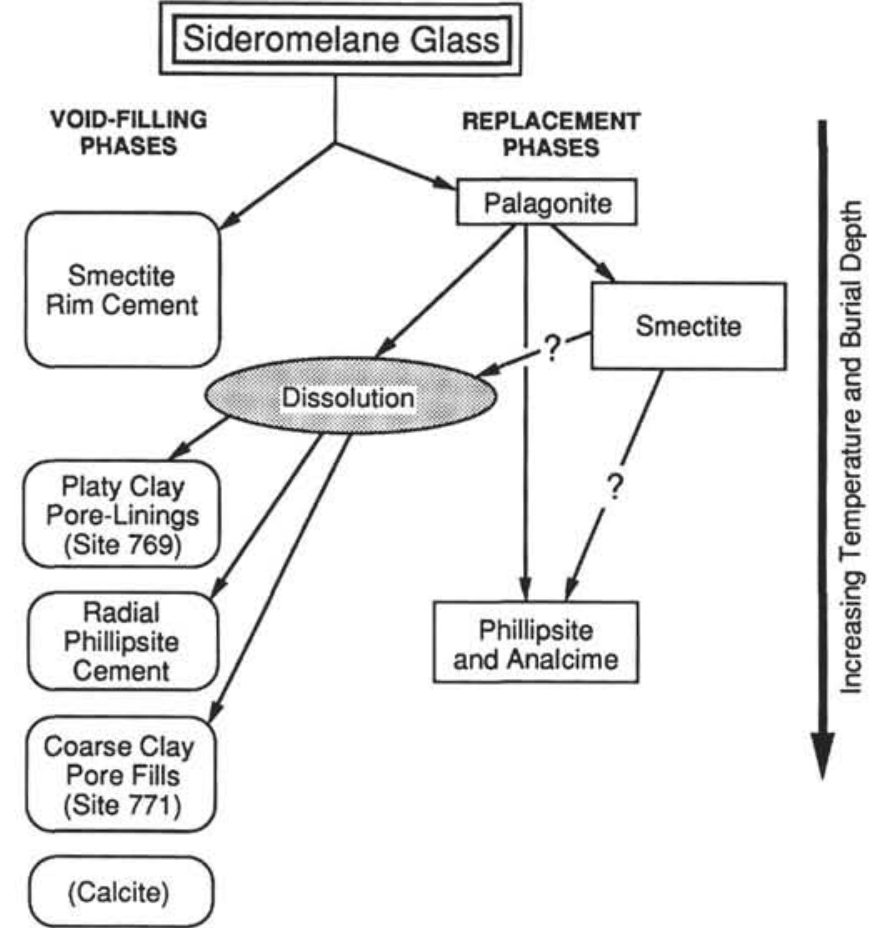

Figure 8. Inferred paragenetic sequence of minerals replacing basaltic glass and filling voids in early Miocene tuffs at Sites 769 and 771. was accompanied by precipitation of the smectite rim cement. Subsequently, the interiors of some clasts (poorly crystalline smectite, palagonite, or glass) were dissolved, creating secondary porosity. At Site 769 , dissolution was followed by precipitation of thin layers of platy clay (smectite?) lining pore spaces. Most remaining interconnected pore space was then filled at both sites by radial phillipsite cement, accompanied by replacement of the interiors of some vitric grains by phillipsite and analcime. Replacement phillipsite occurs at shallower depths at both sites than does analcime, suggesting that analcime is the later phase, but textural evidence is inconclusive. At Site 771, phillipsite cementation was followed by precipitation of coarse clay in some remaining pores, and traces of late calcite cement occur sporadically at both sites.

\section{Diagenetic Conditions}

Basaltic tuffs alter to combinations of clay minerals and zeolites under a wide range of conditions, from near-surface subaerial alteration due to contact with cold percolating ground waters to hydrothermal alteration of basalts at depths of hundreds of meters below the seafloor. The isopachous nature of the earliest clay cement in the tuffs at Site 769 and 771 demonstrates that pore spaces were completely filled with an intergranular fluid during diagenesis. Furthermore, "open system" alteration of subaerial tuffs by cold meteoric waters typically produces a wide variety of diagenetic minerals, especially zeolites (Hay and Iijima, 1968). The restricted mineral assemblage seen at the Cagayan Ridge sites is most consistent with alteration at low temperature during burial below the seafloor.

The literature on alteration of seafloor basalts is extensive, and a full discussion is beyond the scope of this paper (see review by Honnorez, 1981). Major alteration types have 
recently been summarized by Gillis and Robinson (1988), who recognized a sequence of alteration zones in the upper oceanic crust and in ophiolites: a seafloor weathering zone (locally absent) is succeeded downward by a low-temperature zone (LTZ), transition zone, and upper dike zone. The association at the Cagayan Ridge sites of smectite with phillipsite and analcime as replacements of glass, and smectite with phillipsite as void-filling phases, is characteristic of alteration in the LTZ. The LTZ can range in depth from the seafloor to depths of at least $660 \mathrm{mbsf}$, and Gillis and Robinson (1988) estimated maximum alteration temperatures of $50^{\circ}$ to $100^{\circ} \mathrm{C}$ in this zone. In the shallower seafloor weathering zone, smectite and phillipsite are also abundant but are accompanied by iron hydroxides, and analcime is absent as a replacement of basalt glass. In the deeper transitional zone, mixed-layer smectite/ chlorite accompanies smectite, more calcic zeolites such as laumontite form, and plagioclase is replaced by albite.

Bass (1976) distinguished between two types of diagenetic clay mineral assemblages in seafloor basalt resulting from low-temperature alteration under different chemical conditions. Oxidative diagenesis occurs in environments in which basalts are in direct contact with oxygenated bottom waters, such as at the seafloor and adjacent to fractures that served as conduits for the downward migration of seawater through a buried sequence of basalt flows. The major minerals produced by oxidative diagenesis are ferric oxides and hydroxides, celadonite, and lesser saponite. Non-oxidative diagenesis occurs in environments with low oxidation rates in which all ferric iron is incorporated into silicate minerals, chiefly saponite and chlorite-smectite; celadonite is a minor phase or is completely absent, and iron oxides and hydroxides are absent (Andrews, 1980; Seyfried et al., 1978).

Saponite is the only significant clay mineral replacing glass or occurring as a void fill at Sites 769 and 771 ; celadonite and iron oxides and hydroxides are absent. Alteration of the basaltic glass at these sites therefore occurred primarily in a non-oxidative environment rather than in contact with well-oxygenated seawater. Prior to precipitation of saponite and phillipsite cements, the high porosity and permeability of the tuffs would have allowed free circulation of pore waters and free mixing with bottom water if the tuffs were exposed at the seafloor. The porewater systems of the tuff sequences therefore must have been sealed off from contact with bottom waters by the deposition of the overlying claystone and marl sequences prior to significant alteration of the basaltic glass. Alteration of the glass likely occurred as a result of low-temperature hydrothermal circulation of pore waters through the sealed tuffs, beginning as temperatures rose during burial.

The alteration products of olivine phenocrysts at Sites 769 and 771 include ferric hydroxides (in "iddingsite") as well as smectite, and it was previously suggested that the smectite replaces "iddingsite." This suggests a very early stage of oxidative diagenesis primarily affecting olivine, which occurred before sealing off the tuff sequence and before extensive alteration of basaltic glass took place.

\section{DISCUSSION}

The lower Miocene pyroclastic sequences at all three Sulu Sea sites have undergone extensive diagenetic alteration at relatively low temperatures $\left(50^{\circ}\right.$ to $\left.100^{\circ} \mathrm{C}\right)$ during burial. The extent of this alteration can be related to a number of factors, including: (1) the high proportion of unstable glass in the tuffs; (2) the high porosity and permeability of the deposits, and the vesicular nature of many of the clasts, resulting in a very high ratio of surface area to volume for the glassy pyroclasts in contact with pore water; and (3) high heat flow and elevated thermal regime related to deposition of the sequences early in the history of a back-arc basin.

The textural relationships and depth distributions of authigenic minerals at these sites illustrate that the mineral assemblages formed during early diagenesis of glass-bearing volcanic and volcaniclastic strata are the result of sequential formation of different phases. They do not represent equilibrium assemblages. Dibble and Tiller (1981) suggest that the sequence of authigenic minerals formed in tuffaceous sedimentary rocks is related to changing pore-water chemistry during alteration of glass and to kinetic factors that favor precipitation of rapidly-growing metastable phases (such as alkali zeolites or cristobalite) rather than a thermodynamically stable phase (such as feldspars and quartz). Changes in the ionic composition and $\mathrm{pH}$ of pore waters can result from changes in the rate of dissolution of glass and from precipitation of authigenic phases. These affects are likely responsible for the common sequence of smectite followed by alkali zeolites seen in altered tuffs of varied compositions. These early reactions involve hydration and dissolution of glass and some pyrogenic minerals (chiefly plagioclase). Later reactions at higher temperatures in altered tuff sequences involve dehydration of earlier diagenetic phases such as the formation of laumontite from heulandite (Surdam and Boles, 1979). The onset of dehydration reactions is seen in the lower part of the silicic tuff sequence at Site 768 in the formation of analcime from clinoptilolite and mordenite. However, analcime in the basaltic tuff of Sites 769 and 771 appears to have formed directly from basaltic glass and plagioclase without an alkali zeolite precursor.

\section{CONCLUSIONS}

1. Lower Miocene pyroclastic sequences in the Sulu Sea have undergone extensive diagenetic alteration, producing smectite and alkali zeolites as the dominant alteration products. These phases have replaced most original glass, and they fill primary and secondary voids sufficiently to firmly cement the tuffs.

2. Primary igneous minerals are less affected by alteration than volcanic glass. Clinopyroxene and hornblende are virtually unaltered, whereas plagioclase has undergone minor to extensive replacement and dissolution. Olivine has been extensively to completely replaced.

3. Smectite was the first authigenic mineral to form at all sites, followed by alkali zeolites. The assemblage of alkali zeolites varies as a function of original composition of the glass and with burial depth (temperature). Phillipsite was the first zeolite to form in the basaltic tuffs at Sites 769 and 771, whereas mordenite and clinoptilolite characterize the dominantly silicic tuffs at Site 768 . Analcime occurs as a later zeolite in the deeper levels at all sites.

4. Diagenesis of the pyroclastic sequences most likely occurred at temperatures between $50^{\circ}$ and $100^{\circ} \mathrm{C}$ during burial. The porous basaltic tuffs of Sites 769 and 771 were altered under reducing conditions, implying that formation waters were isolated from oxygenated bottom water during diagenesis, probably by a seal of impermeable claystone and marl.

5. Extensive alteration was promoted by the large volume of unstable volcanic glass, high porosity and permeability of the deposits, the large reactive surface area of vesicular glassy pyroclasts, and by high heat flow in a back-arc basin setting.

\section{ACKNOWLEDGMENTS}

I would like to thank the geology faculty at Tulane University for making it possible for me to participate on Leg 124, and Owen Mills of Tulane for help with SEM sample prepa- 
ration and operation. John Miller of the ODP Gulf Coast Core Repository helped expedite post-cruise sampling. This research was supported by a grant from the JOI U.S. Science Advisory Committee.

\section{REFERENCES}

Andrews, A. J., 1980. Saponite and celadonite in Layer 2 basalts, DSDP Leg 37. Contrib. Mineral. Petrol., 73:323-340.

Bass, M. N., 1976. Secondary minerals in oceanic basalts, with special reference to Leg 34, Deep Sea Drilling Project. In Yeats, R. S., Hart, S. R., et al., Init. Repts. DSDP, 34: Washington (U.S. Govt. Printing Office), 393-432.

Boles, J. R., 1972. Composition, optical properties, cell dimensions, and thermal stability of some heulandite-group zeolites. Am. Mineral., 57:1463-1493.

Dibble, W. E., Jr., and Tiller, W. A., 1981. Kinetic model of zeolite paragenesis in tuffaceous sediments. Clays Clay Miner., 29:323330.

Fisher, R. V., and Schmincke, H.-U., 1984. Pyroclastic Rocks: New York (Springer-Verlag).

Fiske, R. S., 1969. Recognition and significance of pumice in marine pyroclastic rocks. Geol. Soc. Am. Bull., 80:1-8.

Gillis, K. M., and Robinson, P. T., 1988. Distribution of alteration zones in the upper oceanic crust. Geology, 16:262-266.

Gottardi, G., and Galli, E., 1985. Natural Zeolites: New York (Springer-Verlag).

Hamilton, W., 1979. Tectonics of the Indonesian region. Geol. Surv. Prof. Paper U.S., No. 1078.

Harris, P. G., and Brindley, G. W., 1954. Mordenite as an alteration product of a pitchstone glass. Am. Mineral., 39:819-824.

Hay, R. L., and Iijima, A., 1968. Nature and origin of palagonite tuffs of the Honolulu Group on Oahu, Hawaii. In Coats, R. R., Hay, R. L., and Anderson, C. A. (Eds.), Studies in Volcanology. Mem. Geol. Soc. Am., 116:331-376.

Holloway, N. H., 1982. North Palawan Block, Philippines-its relation to the Asian mainland and role in evolution of South China Sea. AAPG Bull., 66:1357-1383.

Honnorez, J., 1978. Generation of phillipsites by palagonitization of basaltic glass in sea water and the origin of K-rich deep-sea sediments. In Sand, L. B., and Mumpton, F. A. (Eds.), Natural Zeolites: Occurrence, Properties, Use: New York (Pergamon Press), 245-258.

1981. The aging of the oceanic crust at low temperature. In Emiliani, C. (Ed.), The Sea (Vol. 7): New York (Wiley), 525-587.

Iijima, A., 1978. Geological occurrences of zeolite in marine environments. In Sand, L. B., and Mumpton, F. A. (Eds.), Natural Zeolites: Occurrence, Properties, Use: New York (Pergamon Press), 175-198.

Iijima, A., and Harada, K., 1969. Authigenic zeolites in zeolitic palagonite tuffs on Oahu, Hawaii. Am. Mineral., 54:182-197.

Iijima, A., and Utada, M., 1971. Present-day zeolitic diagenesis of the Neogene geosynclinal deposits in the Niigata oil field, Japan. In Gould, R. F. (Ed.), Molecular Sieve Zeolites 1: Am. Chem. Soc., Adv. Chem. Ser. 101:548-555.

Kudrass, H. R., Müller, P., Kreuzer, H., and Weiss, W., 1990. Volcanic rocks and Tertiary carbonates dredged from the Cagayan
Ridge and the Southwest Sulu Sea, Philippines. In Rangin, C., Silver, E. A., von Breymann, M. T., et al., Proc. ODP, Init. Repts., 124: College Station, TX (Ocean Drilling Program), 93100.

Lee, C. S., and McCabe, R., 1986. The Banda-Celebes-Sulu basin: a trapped piece of Cretaceous-Eocene crust? Nature, 322:51-53.

Mascle, A., and Biscarrat, P. A., 1979. The Sulu Sea: a marginal basin in Southeast Asia. In Watkins, J. S., Montadert, L., and Dickerson, P. W. (Eds.), Geological and Geophysical Investigations of the Continental Margins: AAPG Mem., 29:373-381.

Mitchell, A.H.G., Hernandez, F., and Dela Cruz, A. P., 1986. Cenozoic evolution of the Philippine Archipelago. J. Southeast Asian Earth Sci., 1:3-22.

Moiola, R. J., 1964. Authigenic mordenite in the Esmeralda "Formation," Nevada. Am. Mineral., 49:1472-1474.

Phillips, W. R., and Griffen, D. T., 1981. Optical Mineralogy: the Nonopaque Minerals: San Francisco (W. H. Freeman).

Rangin, C., 1989. The Sulu Sea: a back-arc basin setting within a Neogene collision zone. Tectonophysics, 161:119-141.

Seyfried, W. E., Jr., Shanks, W. C., III, and Dibble, W. E., Jr., 1978. Clay mineral formation in DSDP Leg 34 basalt. Earth Planet. Sci. Lett., 41:265-276.

Sheppard, R. A., and Gude, A. J., III, 1969. Diagenesis of tuffs in the Barstow Formation, Mud Hills, San Bernardino County, California. Geol. Surv. Prof. Paper U.S., No. 634.

Shipboard Scientific Party, 1990a. Site 768. In Rangin, C., Silver, E. A., von Breymann, M. T., et al., Proc. ODP., Init. Repts., 124: College Station, TX (Ocean Drilling Program), 195-297. , 1990b. Site 769. In Rangin, C., Silver, E. A., von Breymann, M. T., et al., Proc. ODP., Init. Repts., 124: College Station, TX (Ocean Drilling Program), 299-342.

1990c. Site 771. In Rangin, C., Silver, E. A., von Breymann, M. T., et al., Proc. ODP., Init. Repts., 124: College Station, TX (Ocean Drilling Program), 399-414.

, 1990d. Summary of shipboard results. In Rangin, C., Sifver, E. A., von Breymann, M. T., et al., Proc. ODP., Init. Repts., 124: College Station, TX (Ocean Drilling Program), 415-419.

Surdam, R. D., and Boles, J. R., 1979. Diagenesis of volcanic sandstones. In Scholle, P. A., and Schluger, P. R. (Eds.), Aspects of Diagenesis. SEPM Spec. Publ., 26:227-242.

Vollbrecht, R., and Kudrass, H. R., 1990. Geological results of a pre-site survey for ODP drill sites in the SE Sulu Basin. In Rangin, C., Silver, E. A., von Breymann, M. T., et al., Proc. ODP, Init. Repts., 124: College Station, TX (Ocean Drilling Program), 105111.

Welton, J. E., 1984. The SEM Petrology Atlas. AAPG, Methods in Explor. Ser., No. 4.

Wilson, M. D., and Pittman, E. D., 1977. Authigenic clays in sandstones: recognition and influence on reservoir properties and paleoenvironmental analysis. J. Sediment. Petrol., 47:3-31.

Date of initial receipt: 10 July 1990

Date of acceptance: 27 March 1991

Ms 124B-146 


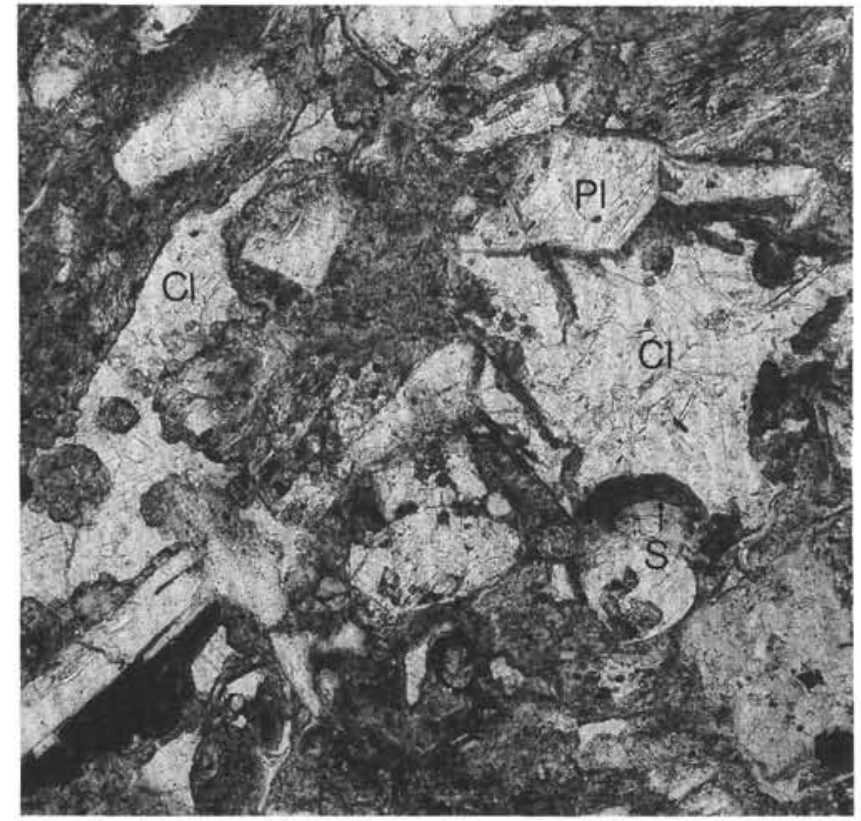

1
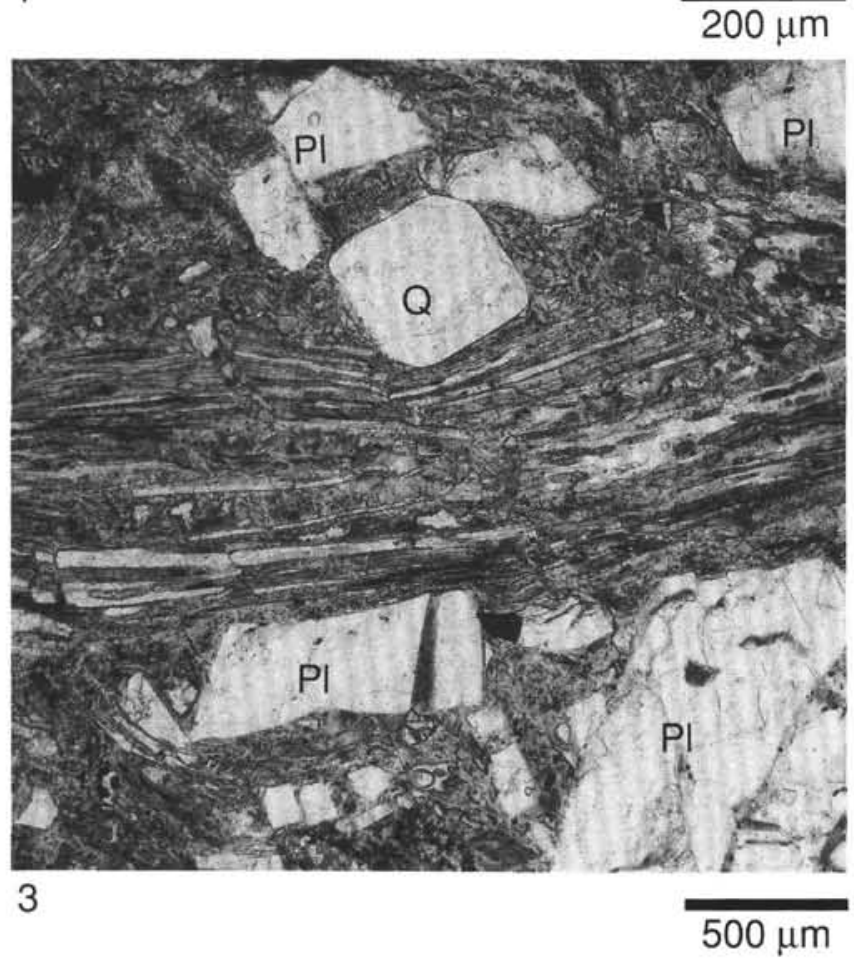
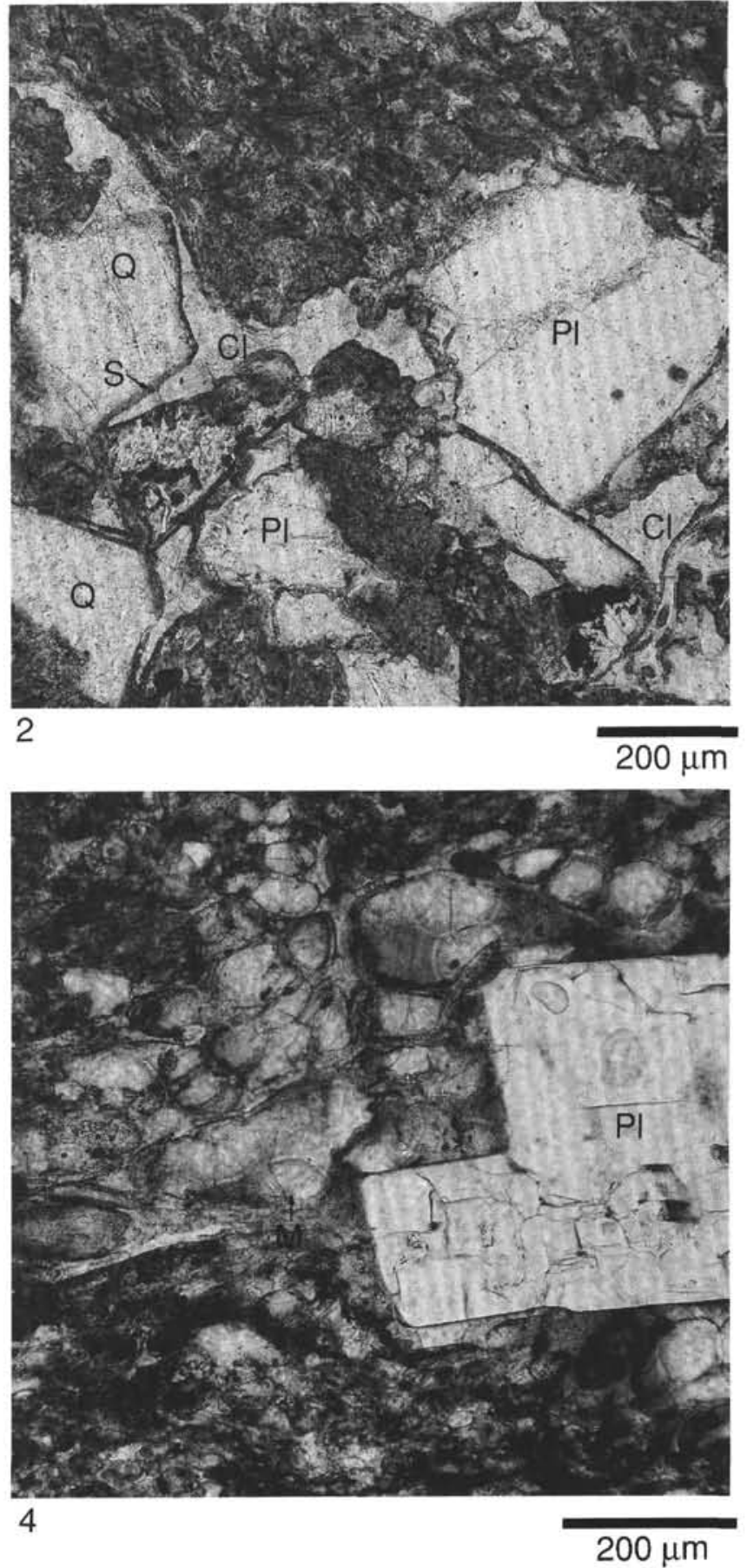

Plate 1. Thin-section photomicrographs of altered siliceous tuff from Site 768, Unit IV, showing typical diagenetic textures. 1. Two pseudomorphs of vesicular glass shards, consisting mostly of randomly-oriented tabular clinoptilolite $(\mathrm{Cl})$. Dark smectite (s) occurs as a ragged rim inside the former outer margin of the shard on the right and fills the small, sparse vesicles within both shards. The clinoptilolite may have filled secondary voids formed by dissolution of glass. Plagioclase (PI) phenocryst is partially replaced, probably by an alkali feldspar (albite or potassium feldspar). Plane-polarized light, Sample 124-768C-52R-5, 78-82 cm. 2. Clinoptilolite (Cl) fills primary pore spaces between pyrogenic quartz (Q), plagioclase $(\mathrm{Pl})$, pumice clasts $(\mathrm{P})$, and other volcanic rock fragments. The primary grains are coated by a thin rim of smectite $(\mathrm{S})$ that precipitated on the walls of pores prior to formation of the clinoptilolite. Plane-polarized light, Sample 124-768C-52R-5, 78-82 cm. 3. Altered pumice fragment broken by compaction between pyrogenic plagioclase $(\mathrm{Pl})$ and quartz $(\mathrm{Q})$ crystals. Glass within the fragment has been altered to clear clinoptilolite $(\mathrm{Cl})$, whereas the long tubular vesicles are filled with dark authigenic clay (chiefly smectite). Plane-polarized light, Sample $124-768 \mathrm{C}-62 \mathrm{R}-2,68-72 \mathrm{~cm}$. 4. Altered pumice clast with large plagioclase phenocryst (PI). The walls of the ovoid vesicles are replaced by clay (chiefly smectite). Vesicles are filled by coalescing radial-fibrous aggregates of mordenite $(\mathrm{M})$ that nucleated on the vesicle walls. Plane-polarized light, Sample $124-768 \mathrm{C}-52 \mathrm{R}-5,78-82 \mathrm{~cm}$. 

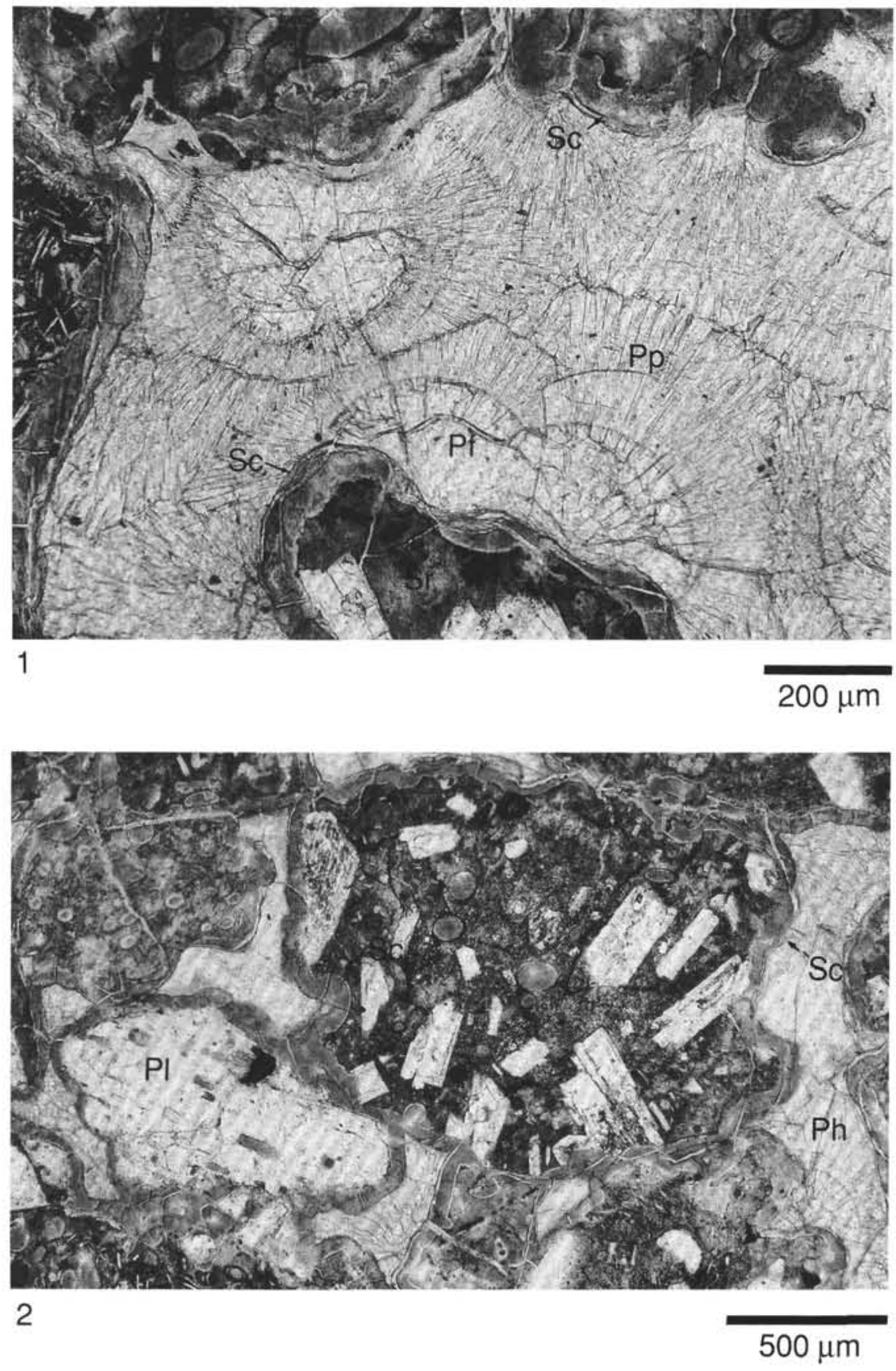

Plate 2. Thin-section photomicrographs of intergranular smectite and phillipsite cements in basaltic tuff in Unit III, Site 769. Sample 124-769C-12R-1, 8-10 cm. 1. Pore lined by crudely isopachous smectite rim cement $(\mathrm{Sc})$, with remainder filled by clear radial aggregates of phillipsite. Centers of phillipsite aggregates are fibrous (Pf), outer parts are prismatic (Pp). Glass in surrounding clasts is replaced by dark smectite (Sr). Planepolarized light. 2. Plagioclase $(\mathrm{PI})$ and varied volcanic rock fragments coated by smectite rim cement $(\mathrm{Sc})$, with remaining void space filled by radial phillipsite aggregates $(\mathrm{Ph})$. Plane-polarized light. 


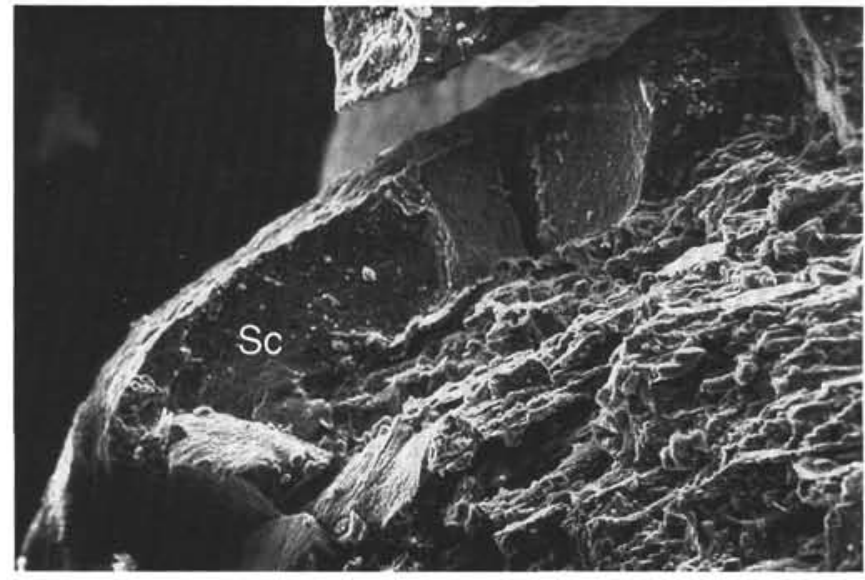

1

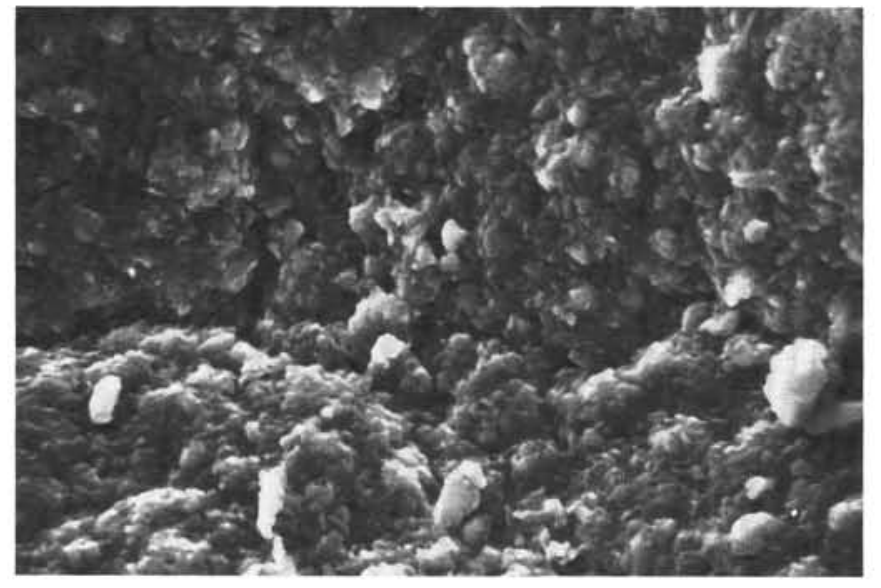

3

$10 \mu \mathrm{m}$

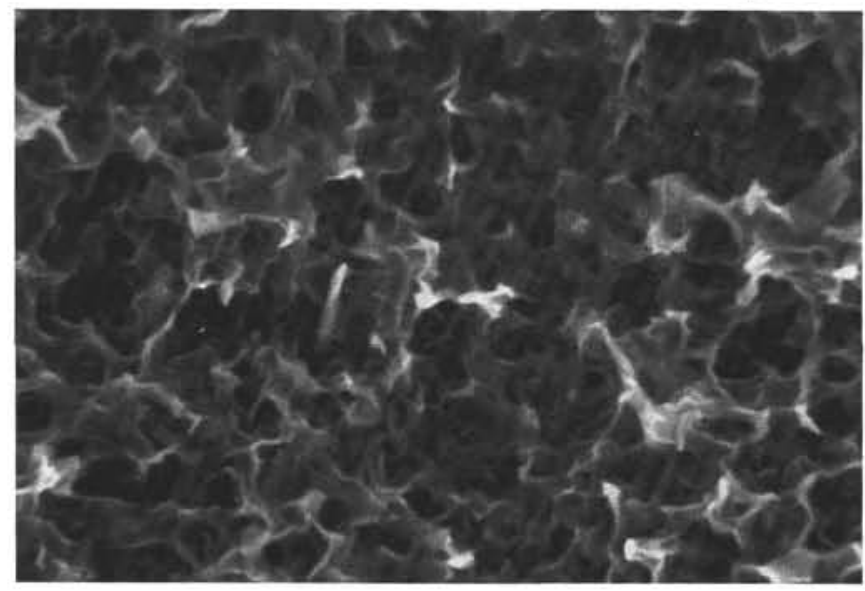

5

$5 \mu \mathrm{m}$

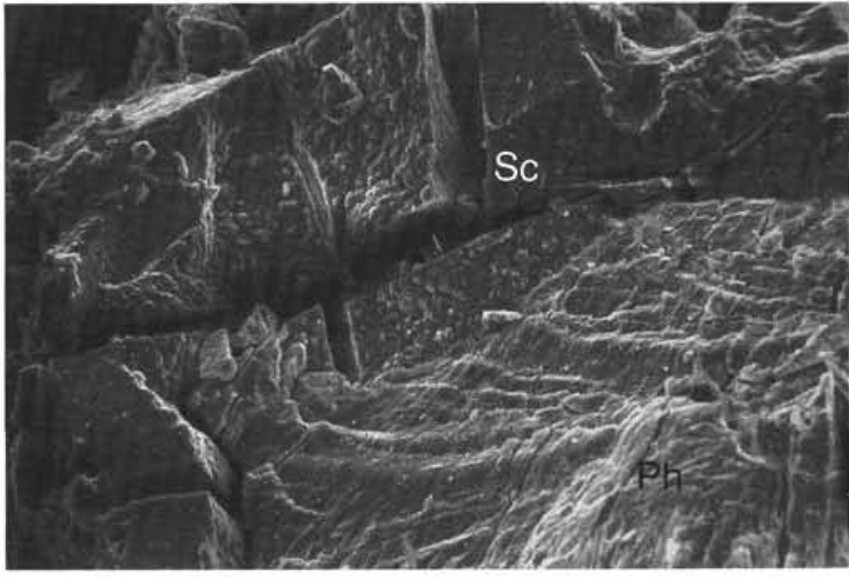

2

$50 \mu \mathrm{m}$

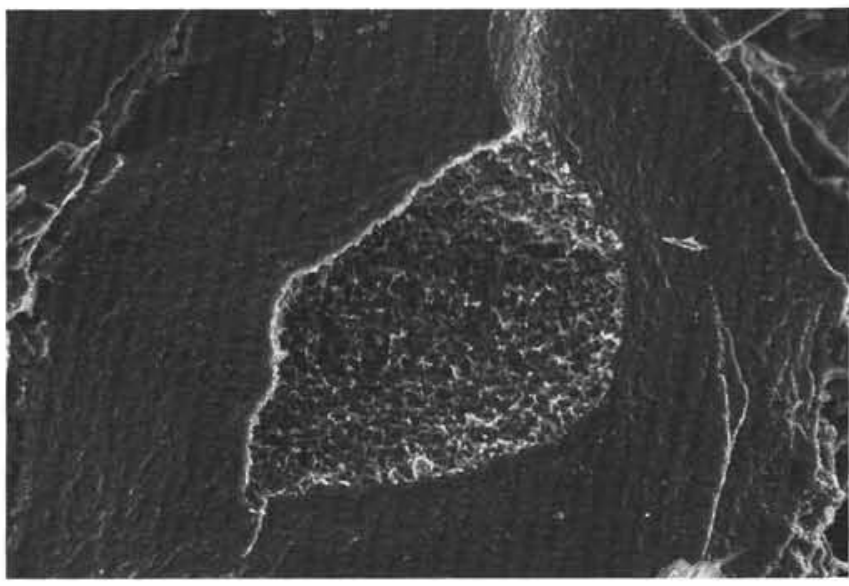

4

$50 \mu \mathrm{m}$

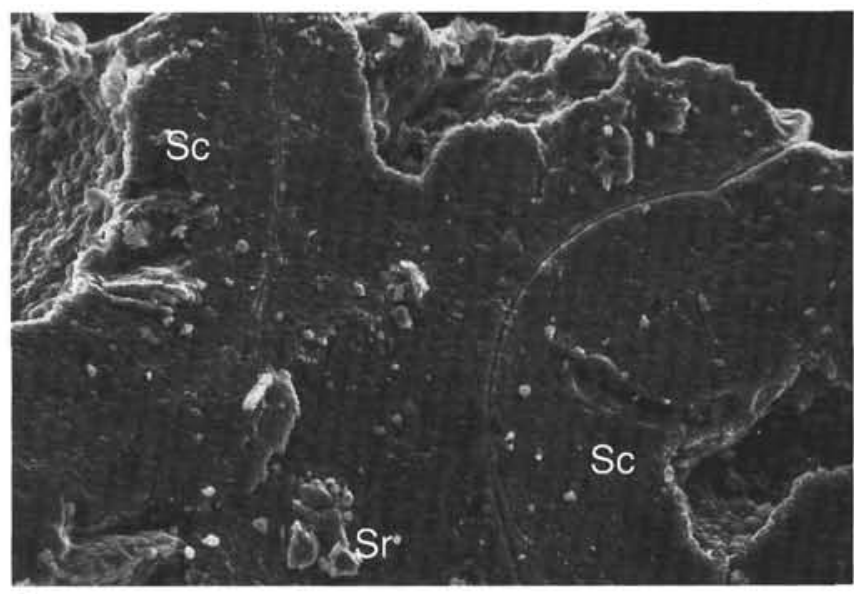

6

$50 \mu \mathrm{m}$

Plate 3. SEM photomicrographs of diagenetic smectite in basaltic tuff in Unit III, Site 769. 1. Cross-sectional view of smectite rim cement (Sc); cement formerly coating surface of basalt clast in lower right has broken away during sample preparation. Note smooth to slightly hackly fracture surfaces across rim cement. Sample 124-769C-12R-2, 105-107 cm. 2. Surface of smectite rim cement (Sc) overlain by prismatic phillipsite cement $(\mathrm{Ph})$. Smectite has fractured during sample preparation. Sample 124-769C-3R-1, 39-42 cm. 3. Detail of outer surface of smectite rim cement, showing characteristic finely pustular surface morphology. Sample $124-769 \mathrm{C}-5 \mathrm{R}-2,98-100 \mathrm{~cm}$. 4. Thick layer of smectite lining open vesicle in basalt clast. Smooth dark areas are fracture surfaces across the smectite, surrounding a central area preserving the free surface of the smectite fill. Sample 124-769C-12R-1, 8-10 cm. 5. Detail of the free smectite surface shown in D, showing web-like or honeycomb surface morphology. 6. Fracture surface across the interior of an altered vesicular glass shard. Void-filling smectite ( $\mathrm{Sc}$ ) lining vesicles is surrounded by smectite (Sr) that has replaced basaltic glass. At top center of photo is the edge of a secondary cavity formed by dissolution of the interior of the vitric clast after marginal replacement by smectite. Sample 124-769B-31X-1, 66-69 cm. 

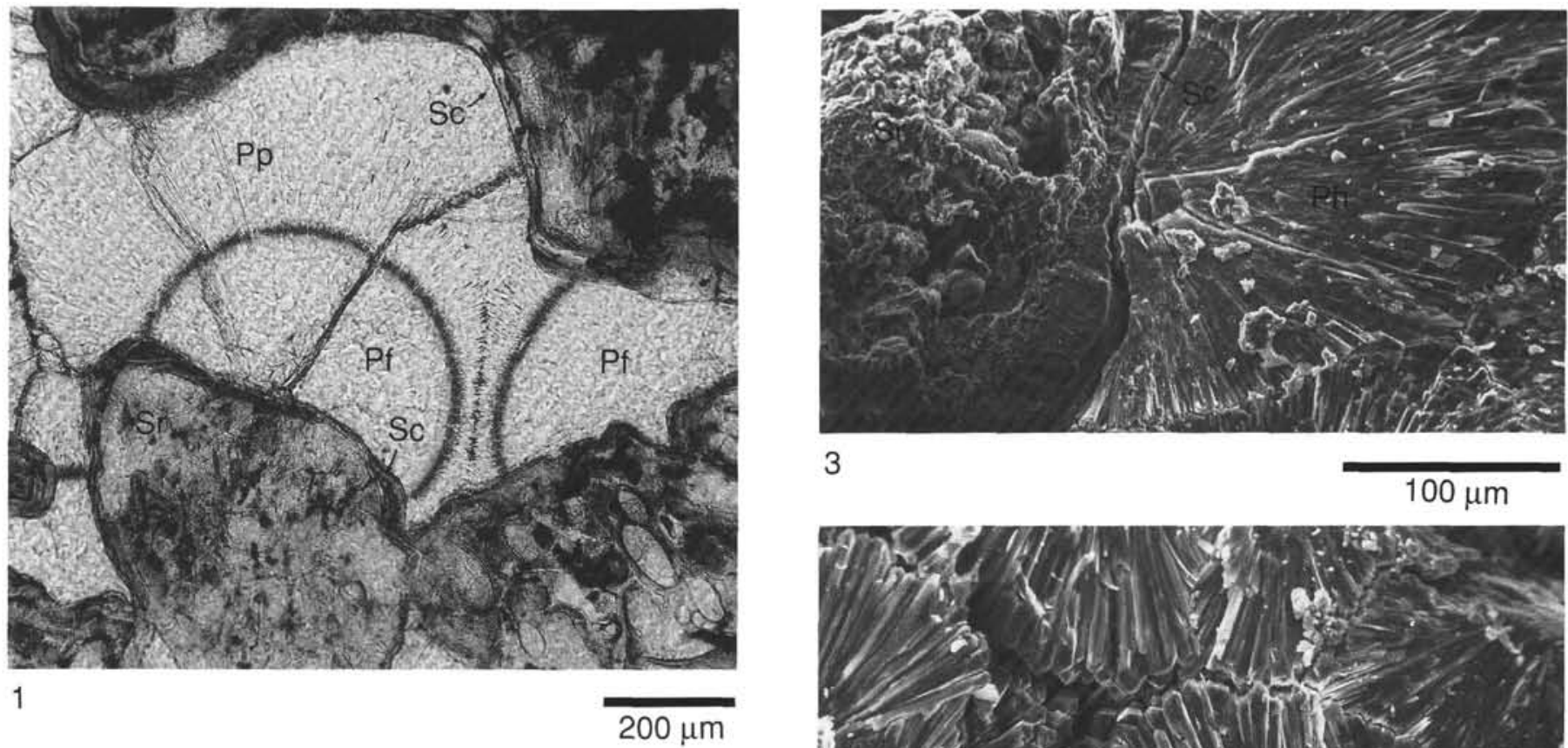

3

$100 \mu \mathrm{m}$

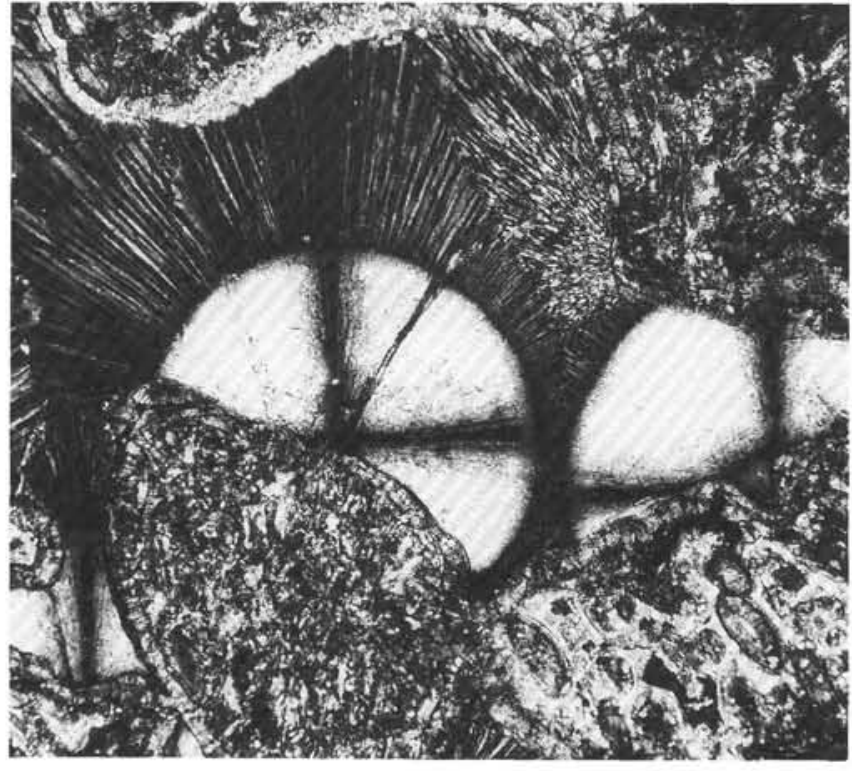

2

$200 \mu \mathrm{m}$

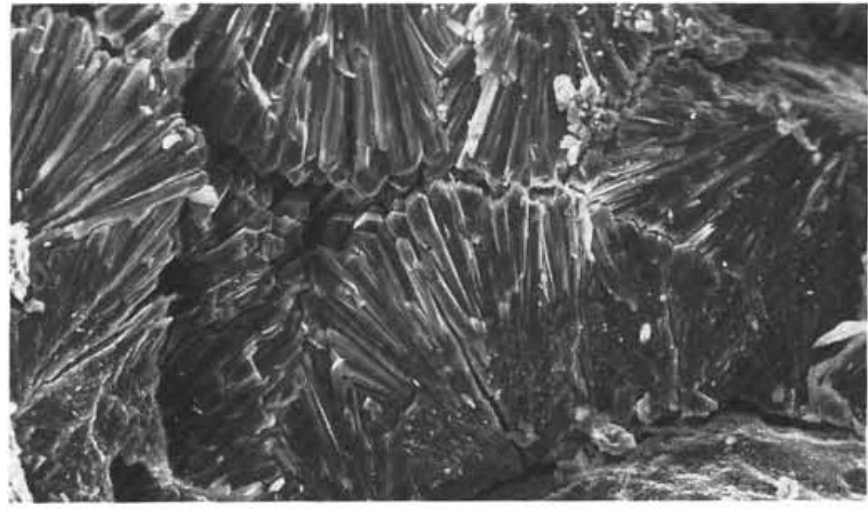

4

$50 \mu \mathrm{m}$

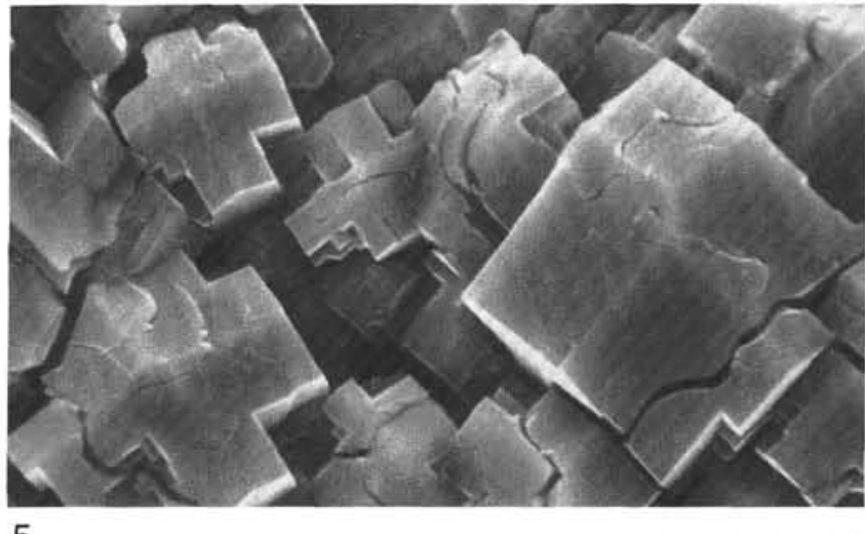

5

$5 \mu \mathrm{m}$

Plate 4. Thin-section and SEM photomicrographs of void-filling phillipsite cement in altered basaltic tuff, Site 769 (Unit III) and Site 771 (Unit IV). 1. Thin-section photomicrograph of intergranular cement. Inner radial-fibrous phillipsite (Pf) is separated from outer radial-prismatic phillipsite ( $\mathrm{Pp}$ ) by a thin dark fibrous zone. The pore is lined by earlier smectite rim cement (Sc), and glass within clasts is replaced by smectite (Sr). Plane-polarized light, Sample 124-769C-3R-1, 39-42 cm. 2. Same view as A, crossed polars. Note higher birefringence of inner fibrous phillipsite compared to outer prismatic phillipsite. 3. SEM photomicrograph. Radial phillipsite cement ( $\mathrm{Ph}$ ) coarsens outward from center and overlies earlier smectite rim cement $(\mathrm{Sc})$ that coats basalt clast replaced by smectite $(\mathrm{Sr})$. Sample 124-769C-8R-6, 105-108 cm. 4. SEM photomicrograph. Several radial phillipsite aggregates fill intergranular pore. Clast surface is in lower right. Note the euhedral terminations of the outer prismatic phillipsite crystals. Sample 124-771-12R-3, 72-74 cm. 5. SEM photomicrograph of euhedral terminations of prismatic phillipsite crystals lining large open vesicle. Square and cruciform cross-sections result from four-fold and eight-fold sector twins joined along the axis of the prism. Sample 124-769C-4R-4, 23-25 cm. 


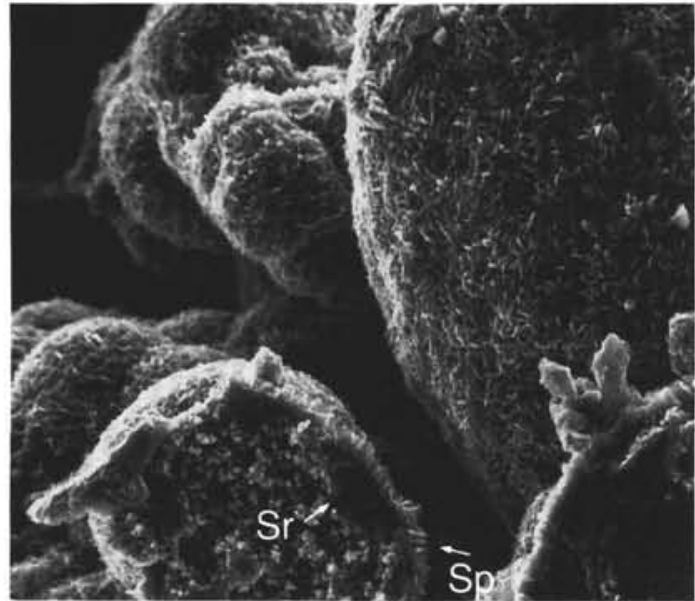

1

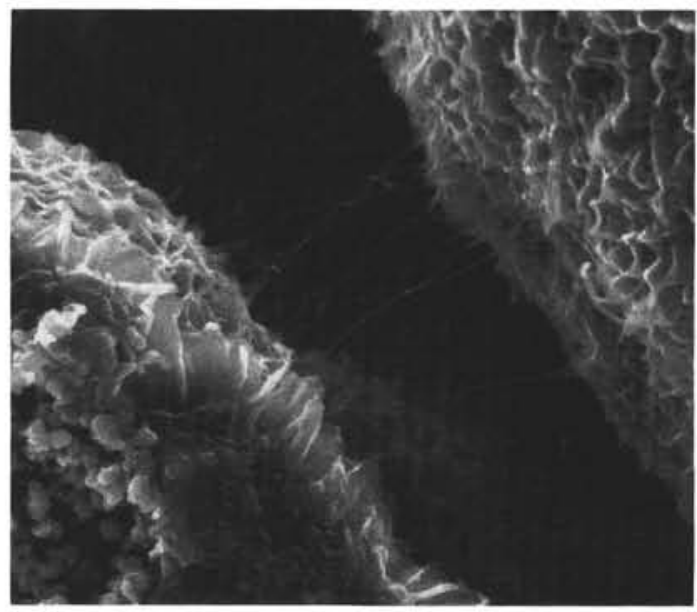

3

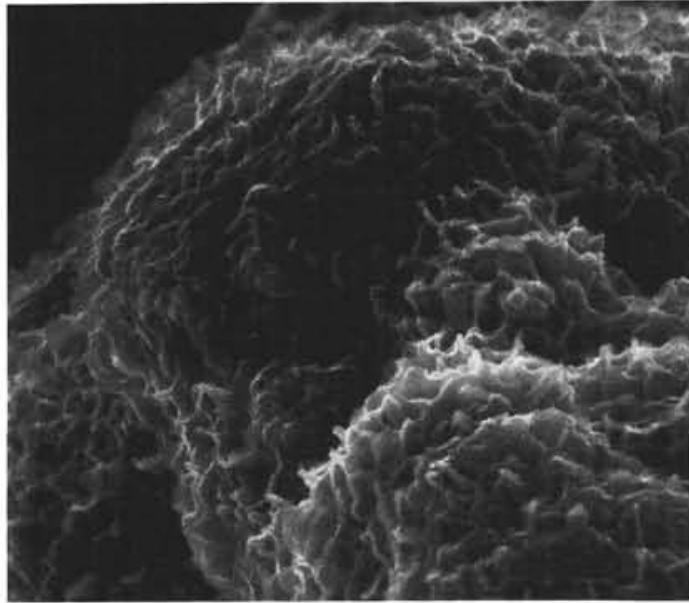

2

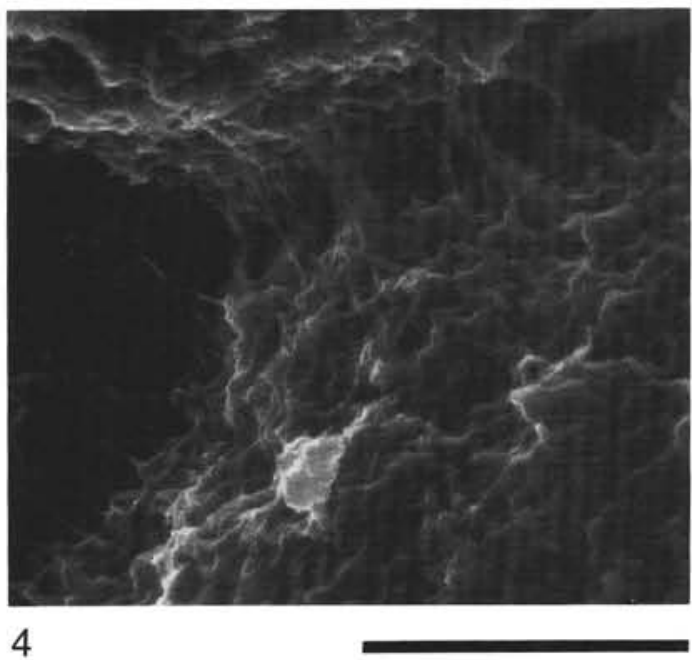

Plate 5. SEM photomicrographs of the hollow interiors of partially dissolved vesicular glass fragments in basaltic tuffs of Unit III, Site 769. Cavities are lined by platy clay coatings. Scale bar for each photo is $10 \mu \mathrm{m}$. 1. Broken clay-filled vesicle in lower left is surrounded by an inner thick layer of replacement smectite ( $\mathrm{Sr}$ ) formed prior to dissolution, and a thin outer layer of platy clay (smectite?, Sp) precipitated from solution after formation of the secondary void. Outer surfaces of other vesicles are covered by the platy pore-lining clay. Sample 124-769C-3R-1, 39-42 cm. 2. Detail of surface of vesicles at top left of A, showing platy, honeycomb surface morphology of platy clay. 3. Detail of bottom center of A, showing slender clay fibers bridging the gap between adjacent clay-coated vesicle surfaces. 4 . Thick fibers and pillars of pore-lining platy clay connect adjacent vesicle surfaces. Sample 124-769B-31X-1, 66-69 cm. 